\title{
KRYZYS PAŃSTWOWOŚCI W POŁOWIE XVII WIEKU. PARALELA DANIA - RZECZPOSPOLITA
}

Abstrakt: W latach pięćdziesiątych XVII w. monarchia duńska oraz Rzeczpospolita znalazły się w fazie ostrego kryzysu, który zagroził ich istnieniu. Podobne pod względem politycznym, społecznym i gospodarczym, dalej jednak poradziły sobie inaczej: w Danii wprowadzono absolutyzm umożliwiający przetrwanie i modernizację państwa, w Rzeczypospolitej reformy nie powiodły się, a kraj pogrążał się w upadku. W Danii natomiast dokonano zmiany pozycji króla, kształtu Kościoła i funkcjonowania duchowieństwa wskutek przyjęcia na początku XVI w. luteranizmu, jako wyznania państwowego.

Słowa kluczowe: Dania, Rzeczpospolita Obojga Narodów, komparatystyka, potop szwedzki.
Abstract: In the 1650s, the Danish Kingdom and the Polish-Lithuanian Commonwealth were hit by a severe crisis that threatened their existence. Although similar in regard to their political, social, and economic systems, both countries dealt with the crisis differently: in Denmark absolutism was introduced, making it possible to modernize the state, while in the Commonwealth reforms failed, and the state descended into downfall. The primary reason was the change of the position of the king and religion, due to the adoption of Lutheranism as the official state church of Denmark in the early sixteenth century.

Keywords: Denmark, Polish-Lithuanian-Commonwealth, comparative studies, Swedish 'Deluge'.

Szwedzki „potop”, kojarzony na ogół z wojną Rzeczypospolitej Obojga Narodów ze Szwecją, w historiografii skandynawskiej określa się jako dwie wojny Karola X Gustawa (1657-1658 oraz 1658-1660). Polska nazwa jednak znacznie lepiej oddaje dramatyzm tego wydarzenia, czy raczej ciągu wydarzeń, ich skali oraz głębokości skutków. Potop szwedzki w dziejach Polski, jeśli chodzi o skalę zagrożenia i konsekwencje, może 
być przyrównany do katastrofy II wojny światowej, a w dawniejszej historii - do najazdu Brzetysława w XI w.

Rzeczpospolita znalazła się na krawędzi - klęska pod Ujściem, wojskowa przewaga Szwedów, okupacja i brutalna eksploatacja kraju i wreszcie traktat w Radnot, to ciąg nieszczęść, które zagroziły dalszemu istnieniu państwa. Tym bardziej że atak szwedzki miał miejsce w momencie poważnego osłabienia Rzeczypospolitej wskutek powstania kozackiego na Ukrainie i wojny z Rosją w latach 1654-1655.

Niedługo po zakończeniu konfliktu ze Szwecją Rzeczpospolita pogrążyła się w wojnie domowej (rokosz Lubomirskiego, 1665-1666), pogrzebane zostały szanse na reformę państwa, a wewnętrzna anarchia pogłębiała się. Wkrótce potem straty terytorialne (rozejm w Andruszowie, 1667), prowadzone ze zmiennym szczęściem wojny z Turcją oraz rosnąca przewaga Rosji w regionie zepchnęły kraj do roli przedmiotu w polityce międzynarodowej. W XVIII w. Rzeczpospolita znalazła się na równi pochyłej. To prawda, że podejmowano liczne i mądre reformy, być może, że rozbiory nie były nieuchronne i że ostateczny rezultat był zbiegiem własnych błędów i fatalnego splotu różnych okoliczności. Faktem jednak jest, że od potopu pogłębiał się upadek Rzeczypospolitej, a w jej składzie - Polski. I faktem też jest, że epokę przednowoczesną obie zakończyły tragicznie: państwo przestało istnieć, naród został podzielony.

Wojna ze Szwecją w latach 1655-1660 była dramatycznym punktem zwrotnym w dziejach jeszcze jednego państwa: Danii. Podobnie jak Rzeczpospolita, Dania była w chwili rozpoczęcia konfliktu poważnie osłabiona: skarb był zrujnowany poprzednimi wojnami (kalmarską oraz trzydziestoletnią), zaś Jutlandia spustoszona inwazją i okupacją wojsk cesarskich w latach 1627-1629. W latach pięćdziesiątych także ten kraj stanął na progu katastrofy, zagrożony unicestwieniem ${ }^{1}$. Także w Danii trauma wskutek tragicznych wydarzeń stała się impulsem do podjęcia dzieła reform. Tu okazały się udane - wprowadzenie absolutyzmu, związana z tym modernizacja państwa oraz początek znoszenia stanowych struktur społeczeństwa pozwoliły nie tylko na okrzepnięcie monarchii, ale też dały jej podstawy do przetrwania kolejnych klęsk, do których doszło w epoce napoleońskiej i później. Faktycznie, od połowy XVII w. nigdy istnienie państwa duńskiego nie było zagrożone (nawet w czasie II wojny światowej), choć jego integralność terytorialna jak najbardziej.

${ }^{1} \mathrm{~W}$ obu przypadkach mamy do czynienia z podobnymi stratami ludnościowymi: wyniosły one w Danii 15-10 proc. (Polska: 20 proc.); E. Ladewig Petersen, Fra standssamfund til rangssamfund 1500-1700. Dansk social historie, t. 3, København 1980, s. 80. 
Nikt raczej nie kwestionuje, że było to możliwe dzięki wprowadzeniu absolutyzmu - zmiana ta umożliwiła, a w każdym razie znacząco przyspieszyła przekształcenie struktur państwowych, skutecznie nadając monarchii bardziej nowoczesny charakter, wiążący się z wprowadzeniem państwa biurokratycznego i sprawnej administracji, zniosła różne przywileje szlachty, wprowadziła równość wobec prawa, a raczej równość w statusie poddanych monarchy. Do tego powstały, początkowo dość ułomne, mechanizmy wewnętrznych reform: okres rządów Chrystiana VI (1730-1746) przyniósł istotne unowocześnienie systemu edukacji oraz kształcenia urzędników, regencja przyszłego Fryderyka VI (1784-1808) ${ }^{2}$ - wiekopomne reformy agrarne (zniesienie poddaństwa chłopów, uwłaszczenie i in.). Prawdopodobnie dzięki tym mechanizmom, ale też dzięki świadomości, w którą wyposażyły Duńczyków - rządzących oraz rządzonych - historia i doświadczenie, w XIX w. doszło - bez rozlewu krwi, wyłącznie wskutek nacisku społecznego, do przekształcenia państwa $\mathrm{z}$ absolutystycznego $\mathrm{w}$ monarchię konstytucyjną.

Porównując Polskę z Danią, Antoni Mączak pisał: „Gra, w drugiej połowie XV w., rozpoczyna się dość podobnie, kończy zgoła odmiennie: w roku 1660 Fryderyk III dokonuje absolutystycznego zamachu stanu, gdy u nas - również po przegranej wojnie, bo trudno wojnę z Karolem Gustawem uznać za zwycięską - Jan Kazimierz abdykuje" ${ }^{3}$. Nasuwa się pytanie, skąd taka rozbieżność biegu wypadków w czasach będących bezpośrednim następstwem takiej samej katastrofy, przy tak wielu dziejowych podobieństwach. Pierwszym i najbardziej oczywistym z nich wydaje się być sama wojna ze Szwecją w latach pięćdziesiątych XVII stulecia i głęboki kryzys państwa, ale analogii poszukamy także głębiej, w ustroju politycznym i kształcie społeczeństwa: jego organizacji i mentalności.

W obu przypadkach wojna ze Szwecją w połowie XVII w. była kolejnym starciem - dzieje konfliktów polsko-szwedzkich i duńsko-szwedzkich wypełniają annały historii nowożytnej Europy Północnej. Żeby nie sięgać zbyt daleko w przeszłość, w XVII w. miały miejsce wojny z Rzecząpospolitą o Inflanty i ujście Wisły (1600-1611, 1625-1629), w przypadku zaś Danii-Norwegii: wojna kalmarska (1611-1613) i wojna Hannibala/ Torstenssona w ramach wojny trzydziestoletniej (1643-1645). Była zatem „tradycja” i doświadczenia. Dodajmy, że w obu przypadkach o sukcesach mogli mówić raczej Szwedzi.

${ }^{2}$ Fryderyk VI koronował się po śmierci swojego ojca, w 1808 r., zmarł w 1839.

3 A. Mączak, Dania i Rzeczpospolita w dobie nowożytnej. Problemy i perspektywy badań porównawczych, ZH 47, 1982, 4, s. 168. 
Główną przyczyną tych konfliktów była rywalizacja o panowanie nad Bałtykiem, angażująca wszystkie kraje regionu, pretekstu zaś do wybuchu wojny w 1655 r. dostarczyły popełnione błędy: polscy królowie uporczywie utrzymywali tytuł królów Szwecji, król Danii Fryderyk III niebacznie sam wypowiedział Szwedom wojnę (czerwiec 1657). Obie strony miały też nieprzyjemne doświadczenia ze zdrajcami, którzy spiskowali na szwedzkim dworze przeciwko własnemu krajowi. Duńskim odpowiednikiem Hieronima Radziejowskiego był arystokrata Corfitz Ulfeldt, zięć zmarłego króla Chrystiana IV, a więc szwagier Fryderyka III (przyrodni, bo małżonka Ulfeldta, Eleonora Krystyna, była córką Chrystiana z morganatycznego małżeństwa ze szlachcianką Kirsten Munk). Jest tu jednak pewna różnica: apele Ulfeldta o przyłączenie się do Karola X Gustawa, jego ataki na króla Fryderyka III spotkały się głuchym milczeniem ze strony duńskiej szlachty - w większości okazała ona, podobnie jak reszta społeczeństwa (oraz ludność Norwegii), wierność wobec tronu ${ }^{4}$. Jest to fakt drobny, ale znamienny i trzeba będzie do niego jeszcze wrócić.

Tak jak Rzeczpospolita, Dania przegrywała starcia wojenne z Karolem X Gustawem. Wskutek jego błyskotliwej kampanii zimą 1657/1658 r. kraj znalazł się faktycznie pod szwedzką okupacją, a w lutym 1658 wojska nieprzyjaciela dotarły na odległość $20 \mathrm{~km}$ od Kopenhagi. Podpisany wkrótce potem pokój w Roskilde przynosił monarchii duńskiej poważne straty terytorialne, obejmujące Skanię, Halland, Blekinge i Bornholm, nie mówiąc o uwolnieniu księcia gottorpskiego od podległości lennej duńskiemu królowi (znowu analogia z przypadkiem Prus Książęcych). Najbardziej niebezpieczna była jednak strata norweskiej prowincji Trøndelag, z miastem Trondheim. Doprowadziła bowiem do rozcięcia Norwegii na dwie części - bez trudu można było sobie wyobrazić dalszą ekspansję Szwecji i utratę przez Norwegię północnych prowincji, głównie Finnmarku.

Ale na tym pasmo nieszczęść się nie zakończyło. Minęło kilka miesięcy i latem 1658 r. Szwecja wznowiła wojnę - Karol X Gustaw pożałował, że nie wykorzystał okazji, którą stworzyły mu zwycięstwa i nie rozprawił się ostatecznie z „,braciszkiem”, jak zwykł nazywać Danię. Historyk Ole Feldbæk pisał o tym, używając słów brzmiących w polskich uszach znajomo: „Celem Karola X Gustawa było wymazanie Danii z mapy Europy"5. Na jesieni 1658 r. rozpoczęło się niemal półtoraroczne oblężenie Kopenhagi, które stało się kulminacyjnym punktem konfliktu. Tak jak

${ }^{4}$ S. Heiberg, Enhjørningen. Corfitz Ulfeldt, København 1993, s. 154; K. Szelągowska, My Norwegowie. Tożsamość narodowa norweskich elit w czasach nowożytnych, Kraków 2011, s. $102-103$.

${ }^{5}$ „Hvor Karl 10. Gustavs mål var at udslette Danmark på Europakortet”, o. Feldbæk, Danmarks økonomiske historie 1500-1840, Herning 1993, s. 30. 
Polacy zachowali w pamięci obronę Częstochowy, tak Duńczycy przez wiele pokoleń pamiętali o oblężeniu stolicy: o królu, który na propozycję opuszczenia miasta dumnie odpowiedział: „umrę w moim gnieździe” i wraz z królową obchodził mury miejskie, dodając ducha obrońcom; o studentach Uniwersytetu Kopenhaskiego, którzy stworzyli własne oddziały i z oddaniem brali udział w walkach, wreszcie o dzielnych mieszczanach, którzy okazali się odważniejsi i bardziej patriotyczni od szlachty. Pamięć o obronie Kopenhagi odegra istotną rolę w dalszych przemianach państwa i społeczeństwa duńskiego.

Ale udział mieszkańców Kopenhagi w walce nie wyczerpuje narodowego charakteru wojny ze Szwecją. Duże napięcia były w prowincjach oddanych Szwecji: na Bornholmie doszło do antyszwedzkiego powstania, do walki partyzanckiej zerwali się też mieszkańcy Skanii. Podobnie jak w Rzeczypospolitej, wojna wyzwoliła narodowe emocje.

Drugą wojnę Karola X Gustawa, już zresztą po jego niespodziewanej śmierci, Szwedzi przegrali. Podpisany w Kopenhadze w 1660 r. pokój zwracał Danii Bornholm i norweski okręg Trøndelag, ale przede wszystkim ucinał plany likwidacji państwa duńskiego i aneksji jego terytorium. I mimo różnych klęsk oraz strat terytorialnych w następnych wiekach, trwanie Danii jako odrębnego państwa - jak się rzekło - nie było nigdy odtąd zagrożone.

Wiele z tych podobieństw (strategia wojenna, narodowy opór, udział „zdrajcy”) można uznać za wynikające po prostu z charakteru i natury siedemnastowiecznej wojny. Dlatego w tej duńsko-polskiej paraleli nie można się do tego ograniczać: jakie analogie dostrzeżemy w odniesieniu do gospodarki, ustroju i kształtu społeczeństwa?

Pierwszy rzut oka na mapę sugeruje, że Rzeczpospolita i Dania to antypody. Wielkie, rozległe państwo na środku kontynentalnej Europy, a obok: maleńka, położona na wyspach Dania. Ale ten kraj to formalnie władztwo Oldenburgów, które obejmuje także (przed 1645 r., czyli pokojem w Brømsebro, który przyniósł pierwsze straty terytorialne): Norwegię, terytoria obecnie należące do Szwecji: Skanię, Halland, Blekinge, Bohuslän, Jämtland, Härjedalen, Gotlandię, ponadto księstwa Szlezwik-Holsztyn, Ozylię, Grenlandię, Islandię i Wyspy Owcze, by wymienić najważniejsze. Bez Grenlandii monarchia liczyła sobie niemal 683 tys. $\mathrm{km}^{2}$, z ziemiami tej wyspy wolnymi od lodu - niemal 1100 tys. A zatem są to wielkości porównywalne do rozmiarów Rzeczypospolitej, liczącej sobie w apogeum rozległości terytorialnej ok. 900 tys. $\mathrm{km}^{2}$ powierzchni ${ }^{6}$.

${ }^{6}$ W 1634 r. Rzeczpospolita liczyła sobie 990 tys. $\mathrm{km}^{2}$, łącznie z Inflantami, Historia Polski w liczbach, t. 1: Państwo, społeczeństwo, red. A. Wyczański [et al.], Warszawa 2003, s. 21. 
Ale to podobieństwo jest dyskusyjne. Wiadomo, że rozległość terytorialna Rzeczypospolitej Obojga Narodów miała ogromny (trudny do jednoznacznej oceny) wpływ na jej rozwój wewnętrzny, natomiast w przypadku monarchii oldenburskiej niekoniecznie. Także dlatego, że komunikacja drogą morską - a ta była w drugim przypadku najpowszechniejsza - była łatwiejsza i tańsza. Poza tym, już wkrótce Oldenburgowie utracili niemal 100 tys. $\mathrm{km}^{2}$ na rzecz Szwecji, nie mówiąc już o tym, że znaczna część rozległych terenów monarchii to były kompletne pustkowia, tylko potencjalnie i w dalekiej przyszłości mogące odegrać gospodarczą rolę. Na ogół więc, mówiąc o monarchii duńskiej w dobie nowożytnej, pozostajemy przy kształcie terytorialnym ograniczonym do Danii właściwej, Norwegii i księstw Szlezwik-Holsztyn, ewentualnie Islandii, zważywszy jej rolę kulturową (i w pewnym stopniu gospodarczą). Jest to około 600 tys. $\mathrm{km}^{2}$.

W przypadku liczby ludności dysproporcje się pogłębiają. W $1645 \mathrm{r}$. w monarchii duńskiej (w okrojonym kształcie - jak wyżej) wynosiła ona 1350 tys. ludzi, czyli w przybliżeniu niemal dziesięć razy mniej niż w Rzeczypospolitej. Różnice są równie wyraźne, jeśli ograniczymy się do centralnych części: Dania liczyła sobie 825 tys. (ze Skanią, bez tej prowincji - 608 tys.), Korona zaś - trzy i pół miliona. Nieco mniejszy kontrast występuje w gęstości zaludnienia: w Danii właściwej było to 14-15 osób na km² , czyli nieco mniej niż w centralnych częściach Korony (Mazowsze i Małopolska), dla których podaje się wielkość 16,87.

Pod względem struktury społecznej oba kraje mieściły się w europejskiej normie, ze społeczeństwem zdominowanym liczebnie przez warstwę chłopską, gospodarczo zaś plasowały się "na wschód od Łaby”, czyli miały gospodarkę rolniczą, nastawioną na uprawę zbóż i hodowlę bydła, korzystającą w XVI w. z koniunktury na żywność i przeżywającą w następnym stuleciu kryzys związany z monokulturowością. Można ten obraz nieco niuansować, wskazując na przykład na merkantylistyczną politykę Chrystiana IV lub na odmienną nieco ewolucję gospodarczą Norwegii, ale są to zjawiska albo w niewielkiej skali, albo peryferyjne - nie zmieniają wiele w obrazie gospodarczym całej monarchii.

Oba kraje należały do słabiej zurbanizowanych ziem w Europie. Ludność miejska w Danii w XVII w. stanowiła średnio ok. $14^{8}$, w Koronie -

${ }^{7}$ Występowało regionalne zróżnicowanie: najgęściej zaludniona była Zelandia (ok. 32 os. $/ \mathrm{km}^{2}$ ), najmniej: Jutlandia i Skania: 10-11, E. Ladewig Petersen, Fra standssamfund, s. 49; Historia Polski w liczbach, s. 20, 22.

${ }^{8}$ Największy odsetek ludności miejskiej zamieszkiwał Zelandię (ponad 22 proc.), najmniej - Skanię (8 proc.), a w Danii właściwej - Jutlandię (12 proc.), E. Ladewig Petersen, Fra standssamfund, s. 46-47. 
18 proc. społeczeństwa. W pierwszej połowie XVII w. w Danii właściwej było około 70 miast: największa była Kopenhaga (1650 - 30 tys. mieszkańców), następnie kilka miast średnich (faktycznie małych), liczących 2-5 tys. (Aalborg, Aarhus, Odense), reszta to miasteczka między 1 a 2 tys. oraz poniżej tysiąca ${ }^{9}$. W Koronie proporcje układały się podobnie, relatywnie dużych miast (powyżej 10 tys.) było mało, przeważały niewielkie $^{10}$. Podobna była dominacja jednego miasta: w przypadku Rzeczypospolitej był to Gdańsk, liczący już w połowie XVI w. 30 tys. mieszkańców, a w połowie następnego stulecia wraz z przedmieściami już około 100 tys. mieszkańców. Ale o ile Kopenhaga pozostawała stolicą państwa, silnie zintegrowaną z całą monarchią, a jej mieszczaństwo potencjalnie mogło stanowić grupę politycznie aktywną, to Gdańsk tej roli nie pełnił - broniąc swej niezależności i gospodarczych interesów, nie angażował się w walkę polityczną toczącą się w państwie polskim.

Kopenhaskie mieszczaństwo było jedyną grupą, mogącą pod względem zamożności i ekonomicznego znaczenia stać się jakąś formą politycznej, alternatywnej wobec szlachty bazy, którą król mógł wykorzystać. W dziejach Danii taka sytuacja już występowała: promieszczańską politykę prowadzili tacy władcy jak Eryk Pomorski w XV w. oraz Chrystian II na początku XVI (w obu przypadkach, obok mieszczan stolicy istotną rolę odegrali wielcy kupcy w Malmø, w Skanii, którą Dania utraciła w 1658 r.). Niechęć kopenhaskiego mieszczaństwa do szlachty była powszechnie znana, podobnie jak jego poczucie krzywdy z powodu niezawinionej i nieracjonalnej dyskryminacji. W Kopenhadze istniał rozwinięty system cechowy, mieszczaństwo było najważniejszym dostawcą towarów przemysłowych dla państwa. Stawało się też coraz bardziej wszechstronne, co odzwierciedla pojawienie się w XVII w. w jego szeregach nowych kategorii: obok wielkich kupców i przedsiębiorców manufakturowych mamy też inwestorów budowlanych, spekulantów mieszkaniowych, akcjonariuszy kompanii handlowych, dostawców dla wojska i finansistów, specjalizujących się w pożyczkach i kredytach dla Korony. Kopenhascy mieszczanie byli nie tylko bogaci, ale też wykształceni, podróżowali za granicę, byli powiązani rodzinnie z elitą intelektualną: wyższym duchowieństwem oraz profesurą tamtejszego uniwersytetu ${ }^{11}$.

Niewątpliwy awans mieszczaństwa symbolizować może zmiana jego podejścia do kwestii politycznych, która dokonała się w ciągu stu lat. Kiedy w połowie XVI w. mieszczanie, w odpowiedzi na pytanie władz

\footnotetext{
9 H.C. Johansen, Danish Population History 1600-1939, Odense 2002, s. 13.

${ }^{10}$ Historia Polski w liczbach, s. 37.

${ }^{11}$ E. Ladewig Petersen, Fra standssamfund, s. 135.
} 
centralnych, pokornie odpowiedzieli, że są wyłącznie „uniżonymi poddanymi Jego Majestatu i szlachty Królestwa Danii", sto lat później otwarcie zażądali "równego szlachcie dostępu do officia et honores"12. Mieszczanie polskich miast królewskich, utraciwszy prawa polityczne w XV w., nie zdołali już ich odzyskać, a ich bierność, jak sądzę, wymyka się prostym wyjaśnieniom.

Dania była jedynym krajem skandynawskim, w którym położenie chłopów zbliżało się do modelu wschodnioeuropejskiego. Wyraźna była tendencja do stopniowego uzależniania tej warstwy od właścicieli ziemi, zwłaszcza na Zelandii. Widać ją w aktach z przełomu XV i XVI w., w tym w królewskich kapitulacjach (Haandfcestning), podpisywanych przez władcę w chwili elekcji: w 1483 r. król Hans ujął to w formule: szlachcic jest królem w swoich dobrach. Poszerzała się pańska jurysdykcja nad chłopami i w kapitulacji Chrystiana III (1536) szlachcic otrzymywał prawo skarżenia, sądzenia i karania chłopów także cieleśnie, włącznie z karą pozbawienia wolności i śmierci (hals og håndsret). Coraz częściej wprowadzano zakaz opuszczania przez chłopa majątku, faktycznie więc szerzyła się praktyka przywiązania do ziemi (vornedskab) oraz podnoszenia pańszczyzny (kontynuowana także w czasach absolutyzmu, po 1660 r.). Jednocześnie malała liczba chłopów właścicieli ziemi. Na początku XVI w. około 10 proc. ziemi należało do nich (głównie na Jutlandii), dwieście lat później było to 2 proc. ${ }^{13}$ Chłopi oddawali dziesięcinę, ale nie utrzymali wprowadzonego w czasach reformacji prawa wyboru księdza w swojej parafii. Recesy królewskie z lat 1547 i 1558 zawierały ogólne sformułowania, że szlachcic ma prawo robić wszystko, co służy zwiększeniu dochodów z jego majątku.

Jednakże duńscy chłopi nie zostali zepchnięci do takiej pozycji jak chłopi wschodnio- i środkowoeuropejscy: ani system poddaństwa nie był tak rozbudowany, ani też pańszczyzna tak dolegliwa. Chłop był przede wszystkim dzierżawcą, a obowiązek pańszczyzny nigdy nie objął całego chłopstwa: szacuje się, że w połowie XVII w. dotyczył ok. 20 proc. gospodarstw chłopskich ${ }^{14}$. O statusie chłopów w XVI w. świadczyć może także fakt, że reces króla Chrystiana III z 1536 r. o wprowadzeniu wyznania protestanckiego jako państwowego został przedłożony do akceptacji nie tylko szlachcie, ale też delegacji mieszczan i właśnie chłopów, co wiązało się również z próbą ogólnonarodowego pojednania po wojnie domowej.

12 Ibidem, s. 19.

13 O. Feldbæk, op. cit., s. 8; http://danmarkshistorien.dk/leksikon-og-kilder/vis/ materiale/selvejerboender-ca-1000-1700/?no_cache=1\&cHash=f1504f1fe8f3c1ddede9e01df2e7300c (dostęp: 2 VII 2017).

${ }^{14}$ E. Ladewig Petersen, Fra standssamfund, s. 352. 
Podobny gest, świadczący o tym, że chłopów mimo wszystko uważano za w jakimś stopniu równouprawnioną część narodu, wykonano w 1660 r., kiedy doszło w Kopenhadze do złożenia uroczystego hołdu Fryderykowi jako dziedzicznemu władcy: zaproszono wówczas delegację wieśniaków, która miała reprezentować stan chłopski ${ }^{15}$.

Historycy podkreślają, że majątek ziemski szlachcica duńskiego bliższy był modelowi Grundherrschaft, dominującemu w Europie Zachodniej, niż Gutsherrschaft, właściwemu obszarom na wschód od Łaby. To prawda, że zwłaszcza w XVI w. widać tendencję do rozwoju folwarku: szlachta konsolidowała swoje majątki, komasowała je w wielkie kompleksy, czasem rugując chłopów, czasem dokonując zamian. Rosło znaczenie gospodarstwa głównego, do którego ściągano rolników, można bowiem wówczas obarczać ich robocizną. Ostatecznie jednak skala tych procesów nie była wielka: ziemia należąca bezpośrednio do szlachcica w Danii nigdy nie przekraczała 10 proc. całości i 5-6 proc. ziemi ornej ${ }^{16}$. Warto też pamiętać, że władcy podejmowali starania, by prawa szlacheckie nie oznaczały samowoli - niewątpliwie największym „przyjacielem chłopów” był Chrystian II, lecz po jego obaleniu większość decyzji monarchy zniesiono. Ale król Fryderyk I w 1523 r. wydał dekret zakazujący usuwania dzierżawcy z ziemi, jeśli wypełniał on swoje zobowiązania, a w dokumencie z $1524 \mathrm{r}$. znalazł się zapis, że szlachcic może zakupić ziemię wolnego chłopa tylko za zgodą króla. Potem taki zapis był wielokrotnie powtarzany przez kolejnych władców, co świadczy z jednej strony o dążeniu do zapewnienia kmieciom pewnej opieki, ale $\mathrm{z}$ drugiej o tym, że szlachta prawa tego nie przestrzegała. Ponadto, istotnie taką zgodę często od króla otrzymywała. W konkretnych zaś sporach między chłopami a szlachtą królowie często brali stronę tych pierwszych ${ }^{17}$. Swoją drogą, zdolność chłopów duńskich do wykorzystania różnych, prawnych sposobów walki o swoje interesy (choć nieporównywalna do tej, cechującej chłopów norweskich czy szwedzkich) świadczyć może o pewnym poziomie świadomości prawnej oraz aktywności publicznej, tym samym nie pozwala traktować ich jak bierną, niewolniczą masę.

Występowanie tendencji do równowagi w sposobie odnoszenia się do szlachty i chłopów widać na przykładzie dość szczegółowej, ale niezmiernie istotnej kwestii karmienia wołów przeznaczonych na handel. Wiadomo, że bardziej opłacało się sprzedawać woły na wiosnę, po tym,

15 B. Scocozza, G. Jensen, Politikens etbinds Danmarks historie, [København] 2004, s. 149.

16 O. Feldbæk, op. cit., s. 12.

17 Zob. K. Szelągowska, o tym, jak pani Lykke z chłopami i królem wojowała, czyli o kobiecie interesu w XVI-wiecznej Danii-Norwegii, „Studia Podlaskie” 19, 2011. 
jak były tuczone przez zimę w oborze. Zabieg ten wymagał jednak sporych nakładów. Okoliczność, że w ciągu pierwszej połowy XVI w. znacząco zmieniły się proporcje, świadczy o tym, jak szybko bogaciła się duńska szlachta: ok. 1500 r. 80 proc. wołów w sprzedaży to tańsze, po letnim wypasie. Pięćdziesiąt lat później 90 proc. wołów to te droższe, po zimowaniu w oborze. Kiedy w recesach królewskich zaczęły pojawiać się zapisy, że szlachta ma prawo żądać od chłopów karmienia jej wołów, ci zaczęli walczyć, by oznaczało to wypas letni, mniej dla nich kosztowny. W rezultacie szlachta musiała ustąpić i zgodzić się na zapisy, że zimowanie w chłopskiej oborze szlacheckich wołów może mieć miejsce tylko po podpisaniu ze strony chłopa dobrowolnej zgody ${ }^{18}$. Opieka Korony nad chłopami mogła też mieć postać doraźnego sprowadzania zboża w czasie głodu. Instrukcja dla panów lennych z 1557 r. mówiła o tym, że rząd bezwzględnie oczekuje zapewnienia przez lokalną administrację chłopom bezpieczeństwa prawnego i poszanowania ich praw ${ }^{19}$. Państwo poczuwało się też do pomocy rugowanym chłopom: oddawano im inne gospodarstwa, w najgorszym razie zwracano opłatę poniesioną w chwili objęcia dzierżawy; do absolutnych wyjątków należało skazanie rugowanych chłopów na żebranie i włóczęgostwo ${ }^{20}$. W czasach Chrystiana IV rozważane były projekty całkowitego zniesienia przywiązania do ziemi oraz zastąpienia pańszczyzny czynszem, przy czym argumentacja wskazywała na ekonomiczne szkody wynikające $z$ istnienia poddaństwa i pańszczyzny. Te instytucje były też krytykowane przez ówczesnych intelektualistów nieszlacheckiego pochodzenia. Co nie zmienia faktu, że równolegle rozwijało się ustawodawstwo represyjne, karzące chłopów za odmowę wykonywania obowiązków ${ }^{21}$.

W sumie system poddaństwa i pańszczyzny nie został w Danii nadmiernie rozbudowany, szlachcic zaś musiał się liczyć z państwem - określenie króla Hansa, że jest „królem we własnym majątku”, było nieco na wyrost.

Choć rosnąca pańszczyzna pogarszała status społeczny chłopów, to o ubożeniu tej warstwy można mówić dopiero po 1630 r., co wiązało się ze spadkiem cen na towary rolne oraz konsekwencjami wojen - głównie okupacją Jutlandii w czasie wojny trzydziestoletniej, epidemiami oraz obecnością wojsk brandenburskich i polskich łupiących kraj w czasach wojen Karola X Gustawa, ale też z rosnącym uciskiem fiskalnym ze strony

\footnotetext{
18 O. Feldbæk, op. cit., s. 19, 38.

19 E. Ladewig Petersen, Fra standssamfund, s. 142-143, 182.

20 Ibidem, s. 359.

${ }^{21}$ Ibidem, s. 350.
} 
państwa i jego ewolucją od państwa dominialnego do państwa podatkowego. Odbywała się ona w gruncie rzeczy kosztem chłopów. Jeśli przyjąć wskaźnik obciążenia ich podatkami nadzwyczajnymi w pierwszej dekadzie XVII w. za sto, to w latach trzydziestych wynosił on 324, w czterdziestych zaś - 548! Co oznaczało, jak pisze Feldbæk, koniec możliwości podatkowych chłopów, ich zubożenie i załamanie gospodarki chłopskiej na sto lat ${ }^{22}$. Dopiero koniunktura połowy XVIII w., a następnie reformy agrarne końca tego stulecia odwróciły ten trend. Można zatem pokusić się o podsumowanie: o ile status prawny i społeczny chłopów duńskich był jednak lepszy od polskich, to ich sytuacja ekonomiczna wykazywała duże podobieństwo: zamożność w wieku XVI, kryzys i upadek w XVII.

Gniew chłopów duńskich wyładował się w buntach, z których największe nasilenie miały te $\mathrm{z}$ lat 1438-1439 i 1441, a przede wszystkim w wojnie domowej z czasów reformacji, tzw. wojnie hrabskiej (Grevens fejde), łączącej różne motywy, zarówno polityczne (walka o tron), religijne (reformacja), jak i społeczne (próba powstrzymania rosnącego ucisku). Dla chłopów, zwłaszcza wolnych właścicieli na Jutlandii, wojna skończyła się klęską i represjami, ale pamięć o tym największym zbrojnym konflikcie wewnętrznym w dziejach Danii pozostała: memento zarówno dla chłopów, jak i szlachty, która dobrze przyswoiła sobie nauczkę: nie eksploatować chłopów nadmiernie, nie dopuszczać do sojuszu króla z niższymi stanami, ale jednocześnie doceniać konieczność utrzymania silnego państwa ${ }^{23}$. Gospodarka rolna w Danii oparta była ponadto na swego rodzaju konsensusie: król, szlachta oraz mieszczanie byli świadomi, że w ich interesie jest, by gospodarstwo chłopskie dobrze funkcjonowało, bowiem jest ono istotnym elementem układu gospodarczego. Ważne było, by chłopi byli w stanie wyprodukować nadwyżki, którymi handlowała szlachta i kupcy, by mogli płacić podatki, potrzebne państwu, by w końcu mogli kupować towary, produkowane lub sprzedawane w miastach. Dlatego, w razie potrzeby, chłopi mogli liczyć na pomoc: ze strony starosty, dziedzica lub kupca ${ }^{24}$.

Sfera, w której podobieństw między Danią a Rzecząpospolitą jest bardzo dużo, to położenie szlachty. Władysław Czapliński, wspominając o pewnych różnicach, o których niżej, konkludował: „Pod innymi względami szlachta duńska przypomina szlachtę polską. Lubi dobrze zjeść i popić, jest kłótliwa, skora do procesowania się z sąsiadami.

${ }^{22}$ O. Feldbæk, op. cit., s. 52; E. Ladewig Petersen, Fra standssamfund, s. 357.

${ }^{23}$ B. Scocozza, G. Jensen, op. cit., s. 122; S. Heiberg, Christian IV - en europceisk statsmand, København 2006, s. 70; E. Ladewig Petersen, Fra standssamfund, s. 181.

${ }^{24}$ O. Feldbæk, op. cit., s. 36. 
Poza tym, jak wszędzie w Europie nosi się wysoko, spogląda z góry na chłopa i chętnie go wykorzystuje" 25 .

Nie bez przyczyny o okresie 1450-1660 w dziejach Danii mówi się: czasy rządów szlachty, Adelsveeldet. Szlachta duńska była stanem niewątpliwie uprzywilejowanym - faktycznym suwerenem w państwie. Jej status regulowały przede wszystkim kapitulacje podpisywane przez władcę. Kolejne różniły się między sobą, ale można w nich wyodrębnić pewien zbiór stale powtarzających się zapisów, zawierający główne uprawnienia stanu. Prawo gwarantowało szlachcie pełną władzę nad chłopami: swobodę podejmowania decyzji wobec dzierżawców i jurysdykcję senioralną (birkeret). Przewaga nad mieszczaństwem wyrażała się w monopolu posiadania ziemi, nad Kościołem - w prawie do mianowania księdza ${ }^{26}$. Ziemia szlachecka była praktycznie nietykalna: kapitulacja króla Hansa zakazywała kupna ziemi szlacheckiej zarówno mieszczaństwu, jak i Koronie. Zgodnie z tradycją szlachta miała wyłączność polowania i połowu ryb (morskich i słodkowodnych). Cieszyła się wolnością podatkową, czyli nałożenie podatku wymagało jej zgody - dotyczyło to także szlacheckich chłopów pańszczyźnianych. Zwyczajowo wolność ta łączyła się z obowiązkiem służby wojskowej, związek ten nabierał jednak coraz bardziej historycznego charakteru, bowiem szlacheckie pospolite ruszenie traciło znaczenie na rzecz wojsk najemnych, zależnych od króla. Miała też najrozmaitsze ekonomiczne uprawnienia, które ułatwiały jej prowadzenie gospodarstw, często kosztem chłopów lub miast (te faktycznie

25 W. Czapliński, Dzieje Danii nowożytnej 1500-1975, Warszawa 1982, s. 57.

${ }^{26}$ Teoretycznie, zgodnie z ideami Marcina Lutra, kapłan miał być wybierany przez wiernych. W praktyce jednak szybko się z tego wycofano i na ogół procedura mianowania księdza luterańskiego (pastora) była częściowo kontynuacją dawnych praktyk, czyli występującego w czasach średniowiecza ius patronatus. Szlachcic był, obok króla, głównym patronem (czyli faktycznie właścicielem) kościołów. Po reformacji zaczęto wprowadzać różne rozwiązania narzucające duchownym konieczność kształcenia się (zob. s. 328). Realizując swoje prawo powołania (ius vocandi), szlachcic musiał wówczas brać pod uwagę kwalifikacje kandydata. Rolą księdza było kaznodziejstwo, nauczanie, udzielanie sakramentów i opieka nad biednymi, natomiast zarząd kościołem (także w sferze ekonomicznej) powierzano osobnym urzędnikom (kirkevœrgere), też zresztą zależnym od pana lennego. Z czasem prawo patronatu szlacheckiego zwiększało swój zasięg, nie tylko rosła liczba szlacheckich patronów kościołów, ale też ich uprawnienia (np. otrzymywali prawo do kościelnych dziesięcin). Tam, gdzie kościół nie miał szlacheckiego patrona, pastora wybierała wspólnota parafialna, a w miastach burmistrz i rada miejska (Schultz Danmarkshistorie. Vort folks historie gennem tiderne skrevet af danske historikere, t. 2, red. A. Friis, A. Linvald, M. Mackeprang, København 1941, s. 747; M.S. Lausten, Danmarks kirkehistorie, København 1987, s. 132; J. Stenbæk, kaldsret i Den Store Danske, http://denstoredanske.dk/index.php?sideId=103162 [dostęp: 9 VI 2018]; S. Imsen, H. Winge, Norsk historisk leksikon. Kultur og samfunn ca. 1500 - ca. 1800, Oslo 1999, s. 321). 
pozbawione były gwarancji monopolu na rzemiosło czy handel). Przykładowo w 1513 r. prawo precyzowało, że szlachta może prowadzić handel nie tylko na własne potrzeby, w 1523 r. przyznano jej przywilej przejmowania grzywien płaconych przez chłopów. Uzyskała częściowe zwolnienie z płacenia dziesięciny. Wedle zapisów z 1524 r. tylko szlachta, Kościół i Korona miały prawo karmienia wołów zakupioną paszą - chłopi i mieszczanie mogli do tego celu używać wyłącznie paszy przez siebie wyprodukowanej, co znakomicie ograniczało możliwość ich ekonomicznej ekspansji.

Ale największe znaczenie miały prerogatywy polityczne: szlachta miała monopol na większość urzędów państwowych, a przed reformacją także na wyższe urzędy kościelne, w lokalnej administracji oraz na zasiadanie w instytucji współrządzącej: Radzie Królestwa. Za jej pośrednictwem wybierała króla, bowiem monarchia była formalnie elekcyjna, choć faktycznie od połowy XV w. w obrębie dynastii Oldenburgów. Na szczęście dla Duńczyków problemy z sukcesją objawiły się dopiero w połowie XIX w., kiedy już w żaden sposób nie mogły zagrozić stabilności kraju. Większość kapitulacji zawierała też prawo do oporu i wypowiedzenia posłuszeństwa królowi, jeśli ten łamał prawo, a nawet bardziej konkretnie: jeśliby sprzeciwiał się decyzjom Rady Królestwa. Oczywisty był zakaz więzienia szlachcica bez wyroku sądu - taki zapis znalazł się w pierwszej duńskiej kapitulacji królewskiej z 1282 r.

Do wątku politycznego za chwilę wrócimy, teraz zwróćmy uwagę na jedną kapitalną różnicę między szlachtą Rzeczypospolitej a Danii: liczebność, a w związku z tym, też charakter. Ta pierwsza, to wedle obecnych szacunków około 8 proc. społeczeństwa, czyli wielotysięczna rzesza ludzi, różniących się majątkiem, statusem, wykształceniem, poglądami, wyznaniem i narodowością. Oczywiście dużo ich łączyło, dzięki czemu stanowili grupę wyraźnie oddzieloną od reszty społeczeństwa. Tymczasem szlachta duńska to niewielka grupa, nawet w skali zachodnioeuropejskiej. Nie wdając się nadmiernie w szczegóły, stwierdzimy, że w połowie XVII w. liczyła sobie ok. 1800 osób (obojga płci), czyli 0,25 proc. społeczeństwa! Ludzie ci należeli do 155 rodzin szlacheckich ${ }^{27}$.

Mimo tej uderzającej różnicy w liczebności można jednak zaobserwować podobne przeobrażenia społeczno-demograficzne, jak wymieranie i wymiana rodzin, ewolucyjna przemiana rycerstwa w ziemiaństwo, a przede wszystkim koncentracja dóbr, która w Danii prowadziła, wraz z innymi czynnikami (np. obowiązkiem posiadania nazwiska rodowego), do przekształcania się stanu w zamkniętą kastę, uważającą się

${ }^{27}$ H.Ch. Wolter, Adel og Embede. Embedsfordeling og karrieremobilitet hos den dansk-norske adel 1588-1660, København 1982, s. 37; E. Ladewig Petersen, Fra standssamfund, s. 120. 
za suwerena w państwie. Była ona w pewnym stopniu zróżnicowana, choć przypomina odwróconą piramidę. Na szczycie plasuje się szlachta, a raczej arystokracja zasiadająca w Radzie Królestwa i piastująca funkcje starostów (højadel), niżej ziemiaństwo - zamożne, ale bez ważniejszych urzędów (landsadel, magnatadel), następnie szlachta uboższa oraz szlachta pozbawiona ziemi (lavadel, tjenesteadel). Te najniższe kategorie wyraźnie zanikały - ludzie przechodzili do stanu chłopskiego, albo pozostawali „na służbie” możniejszych od siebie, ich status szlachecki ulegał zatarciu, a ziemia wchłaniana przez majątki arystokratów ${ }^{28}$. Przytoczmy najważniejsze dane: w 1625 r. w grupie około 500 właścicieli majątków szlacheckich różnych rozmiarów jedna trzecia dóbr obejmowała 75 proc. ziemi, pozostałe dwie trzecie -22 proc. (w tej grupie połowa -10 proc.) ${ }^{29}$. Świadectwem ,arystokratyzacji” szlachty jest wzrost odsetka szlachty wyższej: w połowie XVI w. było to 30 proc., w 1600 - 40 proc., w 1660 r. 49 proc. Do tego doliczono się, że w latach 1536-1660, 12 rodzin, czyli 4 proc. wszystkich, zajmowało 41 proc. stanowisk w Radzie Królestwa, zaś w 1625 r. 10 proc. ziemi uprawnej było własnością 14 członków Rady ${ }^{30}$. Arystokracja pozostawała w skali całego stanu nieformalnie uprzywilejowana: dzięki majątkowi i udziałowi w rządzeniu miała większe szanse na wszelki awans, karierę oraz skuteczniej gromadziła dobra materialne.

W ten sposób można powiedzieć, że duńska szlachta przypomina raczej polsko-litewską magnaterię, choć pewne zakłopotanie budzi fakt, że nasza magnateria dysponowała rzeszą podporządkowanej sobie klienteli, której arystokraci duńscy nie mieli i mieć nie mogli. Dlatego też zapewne realizowali swoje państwowotwórcze instynkty w obrębie państwa duńskiego, a nie obok, w alternatywnych strukturach. Z tym wiąże się także inny fakt, na który zwrócił uwagę Antoni Mączak: rosnąca więź szlachty duńskiej z państwem. „Ujmując rzecz zwięźle, dostrzegamy w Danii i Szwecji zjawisko zgoła obce stosunkom panującym w Rzeczypospolitej: król kształci i wychowuje, wciąga do zhierarchizowanego aparatu państwowego znaczną część - nawet gros - młodych szlachciców myślących o karierze publicznej”31. Polski uczony zwrócił również uwagę

${ }^{28}$ Do osłabienia niższej szlachty przyczyniła się też reformacja: likwidacja klasztorów zniosła miejsca, gdzie można było, bez szkody dla majątku rodziny, ulokować młodsze dzieci, E. Ladewig Petersen, Fra standssamfund, s. 194.

${ }^{29}$ E. Ladewig Petersen, Kryzys szlachty duńskiej 1580-1660, w: Europa i świat w początkach epoki nowożytnej, cz. 1: Społeczeństwo, kultura, ekspansja, red. A. Mączak, Warszawa 1991, s. 156.

30 A. Mączak, Rządzacy i rządzeni. Władze i społeczeństwo w Europie wczesnonowożytnej, Warszawa 1986, s. 179.

31 A. Mączak, Dania i Rzeczpospolita, s. 175. 
na to, że w monarchii duńskiej od lat trzydziestych XVI w. praktycznie nie występuje zjawisko klientelizmu w żadnej postaci ${ }^{32}$.

Do tego spostrzeżenia jeszcze wrócimy, tu zauważmy: specyficzna struktura i liczebność stanu szlacheckiego w Danii powodowała, że nie było komu organizować sejmików ani też rokoszy i konfederacji. Innymi słowy, nie rozwijały się, zabójcze w realiach epoki nowożytnej i w tak rozległym terytorialnie państwie jak Rzeczpospolita, instytucje demokracji bezpośredniej, a państwo bardziej przypominało oligarchię. Nie było średniej szlachty, która w Polsce stanowiła istotny podmiot polityczny, osłabiający zarówno magnaterię, jak i króla. Jednocześnie jednak średnia szlachta w Rzeczpospolitej nigdy nie była na tyle silna, by skutecznie wymóc trwałe reformy państwa, a jej gospodarcza jednostronność skazywała ją na powolny upadek w czasach ekonomicznego kryzysu. Wraz z jej słabnięciem, słabły wszystkie demokratyczne instytucje w państwie. W Danii średnia i drobna szlachta faktycznie nigdy (o wyjątkach niżej) nie stanowiła odrębnego podmiotu politycznego: siłę uzyskać mogła tylko w sojuszu z nieszlacheckimi stanami. Niezależnie od tych różnic, w obu krajach mamy do czynienia ze stanem szlacheckim, który stanowił potężny, uprzywilejowany podmiot polityczny, na bieżąco uczestniczący w zarządzaniu państwem. Podmiot, bez którego nie zapadały żadne decyzje: „nic o nas bez nas”.

W sferze organizacji państwa zaznaczała się, związana z charakterem szlachty duńskiej, właściwie arystokracji, jedna, duża różnica: inaczej wyglądała reprezentacja stanowa w najszerszym znaczeniu. O ile w czasach średniowiecza sytuacja była podobna, czyli istniała Rada Królewska, doradczy organ złożony z najważniejszych urzędników państwowych i kościelnych, a zarazem możnowładców, o tyle od $1282 \mathrm{r}$. rozwijało się zgromadzenie wszystkich wolnych: rycerstwa i duchownych, czyli Danehof (na lokalnym szczeblu landsting). W XV w. jednak Danehof zanikł (ostatni zebrał się w 1413 r.), lokalny ting stracił znaczenie, a na placu boju pozostała Rada Królewska. Uległa ona ewolucji, przekształcając się z Consilium Regis w Radę Królestwa, czyli Consilium Regni (Rigsrådet) ${ }^{33}$. Zmiana znacząca, odzwierciedlająca kierunek, w jakim w drugiej połowie XV w. szło państwo duńskie: rządy szlachty. Nie miejsce tu, by analizować przyczyny tej przemiany, wymieńmy więc tylko najważniejsze z nich (obok konfliktów ze Szwecją i niepokojów wewnętrznych): zawirowania schyłku rządów Eryka Pomorskiego i pozbawienie go władzy oraz wyniesienie na tron Krzysztofa Bawarskiego. To wówczas właśnie doszło do, jak mówią

\footnotetext{
32 A. Mączak, Rządzaccy i rządzeni, s. 142.

33 Schultz Danmarkshistorie, s. 294.
} 
duńscy historycy, systemowej zmiany, systemskiftet, bowiem wygnanie Eryka Pomorskiego ostatecznie przesądziło o kształcie państwa: Dania miała być monarchią elekcyjną.

Dodajmy, monarchią stanową, jako że nadal (aż po wprowadzenie absolutyzmu) funkcjonowała reprezentacja stanowa, czyli zjazdy stanów (stæendermøde), teoretycznie spotkanie reprezentantów wszystkich mieszkańców, ale zdominowane przez szlachtę. Takie zjazdy, będące kontynuacją zarówno landstingu, jak i Danehofu, nie miały uregulowanych procedur ani kompetencji. Utarła się natomiast praktyka, że odbywały się w chwili istotnych przesileń albo ważnych decyzji, które wymagały legitymizacji większej, niż tylko wola króla lub Rady. Przykładowo taki zjazd odbył się w Kopenhadze w październiku 1536 r., by zaakceptować decyzję Chrystiana III odnośnie do wprowadzenia nowego wyznania w kraju. W zjeździe udział brała szlachta viritim oraz przedstawiciele duchowieństwa, mieszczan i chłopów. W XVII w. zjazd stanowy formalnie dokonywał wyboru króla (w XVI w. decyzja ta należała do Rady Królestwa), a następnie składał mu hołd i przysięgę wierności. Innym ważnym uprawnieniem była zgoda na nadzwyczajne podatki i zwłaszcza w czasach wojen Chrystiana IV konieczne było zwoływanie stanów, by taką zgodę uzyskać (w tym czasie chłopi już nie brali udziału w zjazdach). Dzięki temu w czasach panowania tego króla zarysowała się tendencja do aktywizacji szlachty niższej, o czym będzie jeszcze mowa. Równolegle, analogiczne zjazdy stanowe, tyle że przez cały czas z udziałem reprezentantów chłopstwa, odbywały się w tym czasie w Norwegii.

Jednak najważniejszą instytucją, przez którą realizowały się rządy szlachty, była Rada Królestwa. Pochodzący z przełomu XV i XVI w. bardzo popularny polityczny pamflet opisywał tę instytucję następująco: „Nie ma żadnej wątpliwości co do władzy radców, bowiem oni, oraz mieszkańcy w królestwie elekcyjnym są prawdziwymi i niekwestionowanymi właścicielami samego królestwa, bowiem suwerenność oraz rzeczywiste prawo własności królestwa im bez wątpienie przysługuje" ${ }^{34}$. Gwarancją tego stanu rzeczy miała być elekcyjność tronu. Tekst kończył się zaleceniami, pod którymi zapewne podpisałby się każdy polski szlachcic: „Należy zwrócić uwagę na to, jak radcy oraz mieszkańcy królestwa elekcyjnego muszą być ostrożni i uważni, aby wskutek niedbałości oraz zaniedbań nie doszło do przekształcenia ich królestwa elekcyjnego w dziedziczne;

34 „Det er ingen Tvivl om Raadernes Myndighed, fordi disse og Indbyggerne i et almindelige Valgrige er de sande og utvivlsomme Ejere af selve Riget, thi Herlighedsretten og den virkelige Ejendomsret til selve Riget er utvivlsomt hos dem", cyt. za: ibidem, s. 391. 
wtedy bowiem radcy i mieszkańcy stracą prawo własności [--] a ich wolność przemieni się w niewolę" 35 . Rada Królestwa była suwerenem i właścicielem państwa jako reprezentacja całego społeczeństwa - charakterystyczne jest, że w drugiej połowie XV w. widziano ją jako ciało reprezentujące wszystkie stany, nie tylko szlachtę. Z czasem to myślenie zanikło i już w XVI w. Rada nabrała charakteru instytucji wyłącznie szlacheckiej, choć w oficjalnej propagandzie zawsze prezentowana była jako czuwająca nad interesem całego państwa i wszystkich mieszkańców. Monarcha, wybierany przez Radę, z kompetencjami określonymi przez kapitulację, był postrzegany jako zarządca państwa, którego zadaniem było realizowanie celów wytyczanych przez Radę. Ideologicznym fundamentem jej uprawnień był arystokratyczny konstytucjonalizm (rigsrådskonstitutionalisme, regimen politicum), czyli idea państwa, w którym suwerenem jest „lud”, praktycznie stany wolne (od płacenia podatków) i w którym władza opiera się na prawie stanowionym ${ }^{36}$.

Po raz pierwszy uprawnienia Rady zostały określone w kapitulacji Chrystiana I Oldenburga w 1448 r.: wybierała ona króla, wobec niego reprezentowała społeczeństwo, jej zgoda była konieczna przy decyzjach o podatkach nadzwyczajnych, ale też wszystkich innych ważnych sprawach. Kolejna kapitulacja, króla Hansa z 1481 r., mówiła o zakazie mianowania członków Rady oraz nadawania starostw bez jej zgody, precyzowała, że w chwili śmierci króla pełna suwerenność i władza przechodzą w jej ręce (ten stan prawny symbolizowała zasada „przejmowania władzy nad twierdzami i ich załogami" - Slottsloven). Zapisano, że szlachta (za pośrednictwem Rady) ma prawo pouczać króla oraz wypowiedzieć mu posłuszeństwo. Uprawnienia Chrystiana II (1513) zostały zwiększone: w kapitulacji pominięto konieczność uzyskania zgody Rady na mianowanie członków Rady i starostów. Panowanie tego władcy było burzliwe, także w związku z jego staraniami o wprowadzenie prawnej ochrony interesów mieszczaństwa i chłopstwa, jako alternatywnej bazy politycznej - śmiały plan jak na początek XVI w.! Wyraźnie antyszlachecką polityką Chrystian zasłużył sobie na miano tyrana i w taki sposób portretowała go szlachecka historiografia epoki. Po jego obaleniu podsunięto następcy, Fryderykowi I (1523), kapitulację, w której wyraźnie zaznaczona była hierarchia: symbolizować mógł ją zapis, że szlachcie

35 „Det bør da først nøje agtes paa, hvor forsigtige og aarvagne og opmærksomme Raader og Indvaanerne I et Valgrige bør være at de ikke ved Skødeløshed og Forsømmelse taaler eller finder sig at deres Valgrige bliver nogen Kongens Arverige; thi da miste Raaderne og Indvaanerne Ejendomsretten [--] og saaledes forvandles Raadernes og Indvaanernes Frihed til Trældom", cyt. za: ibidem.

${ }^{36}$ E. Ladewig Petersen, Fra standssamfund, s. 225-226. 
dozwolone jest budowanie zamków, natomiast miasta muszą wyburzyć swoje mury. Kapitulacja Fryderyka I skupiała się na dążeniu do odwrócenia politycznych decyzji podjętych przez poprzednika - pozycja Rady nie uległa tu większym zmianom - pozostawała niewzruszona ${ }^{37}$.

Wojna domowa w latach trzydziestych, jak to już zostało wspomniane, przekonała szlachtę, że silny władca może okazać się pożyteczny. Stąd po 1536 r. widać zahamowanie tendencji do ubezwłasnowolniania monarchy, a raczej próbę utrzymania pewnej równowagi między królem a Radą. Przykładowo, w kapitulacji Chrystiana III nie pojawił się zapis o prawie do oporu, a do tego Rada zaakceptowała kandydaturę jego syna na następcę tronu. Odbyło się więc coś w rodzaju elekcji vivente rege - nie po raz ostatni. W sumie jednak jej pozycja pozostała potężna. Wzrosło znaczenie zwłaszcza grupy najwyższych urzędników państwa - kanclerza, marszałka, ochmistrza - zgodnie z zasadą: „król nie może rządzić sam". Byli oni faktycznie stale przy królu, natomiast Rada jako całość zbierała się od czasu do czasu.

Rolę Rady widać było wyraźnie w czasach regencji za małoletniości Chrystiana IV. W okresie tym (1588-1596) władzę sprawowało czterech wybranych przez Radę dostojników. Przyjęto wówczas dokument, który miał być czymś w rodzaju konstytucji (co wynikało z ogromnego znaczenia, jakie przywiązywano w Danii do prawa stanowionego). Regenci deklarowali w nim politykę opartą na zasadach utrzymania wyznania ewangelicko-augsburskiego oraz poszanowania prawa i zachowania przywilejów szlacheckich. Kiedy Chrystian osiągnął pełnoletność, odbyła się ceremonia koronacyjna (29 VIII 1596).

W kościele Naszej Marii Panny [Vor Frue Kirke] czterej radcy złożyli królewskie insygnia na ołtarzu. Wszystko było już przygotowane do ceremonii, którą poprowadził biskup Zelandii Peder Winstrup, w asyście biskupów Skanii i Fionii. Peder Winstrup wygłosił łacińską mowę o boskości władzy królewskiej, następnie wypowiedział się po duńsku o znaczeniu koronacji i boskim pochodzeniu władzy. Christoffer Valkendorf [ochmistrz koronny] odczytał kapitulację, z wyjątkiem ostatniego paragrafu, który przeczytał sam król, zanim złożył przysięgę, potem Peder Winstrup namaścił prawe ramię króla i miejsce między ramionami. Namaszczenie oznaczało, że król otrzymał boską sankcję swego urzędu i można mu było powierzyć insygnia jako symbole władzy i obowiązków króla. Najpierw nałożono mu specjalną szatę koronacyjną, podbitą futrem sobola. Następnie przekazano mu miecz i, by ukazać swą gotowość do obrony państwa, starym zwyczajem machnął

37 A. Heise, Frederik I, w: Dansk biografisk Lexikon, t. 5, red. C.F. Bricka, Kjøbenhavn 1891, s. 286. 
nim w cztery strony świata „aż zaświszczało”. Wtedy radcy wzięli koronę tak, że każdy dotykał jej jedną dłonią i razem nałożyli ją królowi na głowę. Jaśniej nie można było pokazać, że król otrzymał ją od Rady ${ }^{38}$.

Ale paradoksalnie pozycja Chrystiana IV nie była tak słaba, jak by można było sądzić. Rada Królestwa na ogół szła mu na rękę, król miał swoje sposoby, by nakłaniać ją do współpracy (m.in. nie zwołując jej posiedzeń i nie zapełniając opróżnionych miejsc). Niezwykle ambitne działania króla, jego wielkie inwestycje budowlane, merkantylistyczne decyzje ekonomiczne oraz imperialna polityka zagraniczna (w tym ekspansja kolonialna) niepokoiły zarówno Radę, jak i resztę szlachty, choć można też odnieść wrażenie, że im czasem imponowały - w końcu karmił w ten sposób patriotyczne ambicje! Rysowało się wówczas także rozchodzenie się interesów arystokracji i niższej szlachty, a ściślej uświadomienie sobie przez tę drugą faktu, że polityka Rady ma na względzie przede wszystkim interes wąskiej grupy oligarchów, a nie całego stanu. Sygnały o tej zmianie pojawiły się za panowania Fryderyka II oraz w czasach regencji, kiedy szlachta m.in. krytykowała reformę administracji lokalnej (o tym niżej). W czasach Chrystiana IV widać ją było w działaniach szlachty wokół tzw. kas prowincjonalnych (Landekister). W 1638 r., czyli już po fatalnym udziale w wojnie trzydziestoletniej, szlachta wyraziła zgodę na nadzwyczajny podatek, nie tylko pod warunkiem, że pieniądze zostaną przeznaczone na obronność, ale też wejdą w skład osobnych budżetów w każdej prowincji, nad którymi pieczę sprawować będą specjalni, wybierani przez lokalną szlachtę komisarze. Kolejny kryzys, spowodowany klęską w wojnie ze Szwecją, miał miejsce po traktacie w Brømsebro (1645): w wyniku podjętych wówczas decyzji instytucja komisarza przekształciła się w stały urząd, wybierany przez

38 „I Vor Frue Kirke lagde de fire rigsråder regalierne på alteret. Alt var nu klart til den fornemme ceremoni, som blev ledet af Sjællands biskop, Peder Winstrup, assisteret af biskopperne af Skåne og Fyn. Peder Winstrup indledte med en latinsk tale om kongedømmets guddommelighed, siden udbredte han sig på dansk om kroningens betydning og øvrighedens guddommelige indstiftelse. Christoffer Valkendorf oplæste håndfæstningen på nær den sidste artikel, som kongen selv læste op, inden han svor sin ed, hvorpå Peder Winstrup salvede kongen på højre arm og mellem skuldrene. Salvingen betød, at kongen var guddommeligt indviet i sit embede og nu kunne få overrakt regalierne som symboler på magten og dens forpligtelser. Først blev han iklædt en særlig kroningsdragt med en kåbe foret med en zobel. Så fik han overrakt rigssværdet, og for at vise sin vilje til at forsvare riget huggede han efter gammel skik mod alle fire verdenshjørner «så det bævede». Derpå tog rigsråderne kronen, således at alle rørte den med en hånd og satte den på kongens hoved. Klarere kunne det ikke vises, at det var fra rigsrådet, kongen modtog den”, S. Heiberg, Christian IV, s. 51-52. 
szlachtę i mający prawo przedstawiania kandydatów na członków Rady. W 1647 r. miał miejsce kolejny krok: komisarz zyskał prawo bezpośredniego wybierania kandydata na członka Rady i poszerzono jego kompetencje. Po śmierci Chrystiana IV, w trakcie bezkrólewia, Rada przerwała ten proces (1648), zmieniając prawo i pozbawiając komisarzy realnego znaczenia. Jak łatwo się domyśleć, nie poprawiło to relacji między Radą a niższą szlachtą.

W tym czasie kryzys państwa duńskiego był widoczny, a król złamany klęskami swojej polityki, ale też rodzinnymi tragediami. Śmierć następcy tronu, księcia Chrystiana (1647) zmusiła króla do paktowania z Radą na temat sukcesji. Do decyzji nie doszło, ponieważ król zmarł (luty 1648), ale kolejny syn króla - Fryderyk - musiał zgodzić się na daleko idące ustępstwa i podpisać kapitulację „najsurowszą ze wszystkich”, jak zgodnym chórem stwierdzają dawni i współcześni historycy. Powtarzano tu wszystkie najważniejsze uprawnienia Rady, przywileje szlachty i zakazy wobec króla, a ukoronowaniem był zapis, który mówił, że w razie różnicy poglądów między Radą a królem, to jej zdanie jest ważniejsze i ma ona prawo prowadzić swą politykę mimo braku zgody ze strony monarchy. Oznaczało to, że po niemal 150 latach pewnej równowagi między królem a Radą wracały czasy pełnych rządów arystokracji, niczym w drugiej połowie XV w. Można dostrzec pewne analogie między duńską Radą Królestwa a Senatem w Rzeczypospolitej czy instytucją senatorów rezydentów, choć kompetencje duńskiego organu państwowego były znacznie większe. Trudno też szukać podobieństw czy różnic między Radą a Sejmem - jego funkcje pełniły raczej zgromadzenia stanowe, o których była mowa wyżej. W przeciwieństwie do Sejmu, stcendermøde spotykały się rzadko i tylko na wezwanie monarchy - nie istniały ustalone reguły, takie, jakie w Rzeczypospolitej wprowadzały artykuły henrykowskie więc ich polityczny wpływ był mniejszy.

Jeśli spojrzymy na formalne uprawnienia króla - co jest rewersem kompetencji Rady i ewentualnie innych zgromadzeń stanowych - to przyznać należałoby, że był to urząd równie słaby, co monarcha w Rzeczypospolitej. Istnieje jednak wiele przesłanek, by twierdzić, że duński król miał pozycję mocniejszą. Po pierwsze, był znacznie bogatszy. Bez kontroli Rady król dysponował swoimi domenami, decydował o wysokości cła na Sundzie - najbardziej dochodowego przedsięwzięcia, mógł też podwyższać inne cła i zaciągać pożyczki. Miał sporą swobodę w mianowaniu urzędników, także na stanowisko członka Rady. Dopiero kapitulacja Fryderyka III poważnie tę swobodę ograniczyła. Od czasów Chrystiana III dokonywała się znacząca, choć budząca też kontrowersje, reforma systemu administracji lokalnej. Chodziło o kształt lenn - czyli 
odpowiedników polskich starostw, które na początku XVI w. zdominowane były przez formę najbardziej przypominającą średniowieczne lenna: pan lenny (lensherre), czyli starosta, zarządzał domeną królewską, wykonywał różne administracyjne obowiązki, w zamian odprowadzając do skarbu królewskiego ustaloną w umowie (reskrypcie nominacyjnym) kwotę. Cała reszta stanowiła jego dochód. Wielka koniunktura na towary rolne w XVI stuleciu nie przynosiła monarsze takich zysków jak szlachcie. Stąd reformy: starostwo miało stopniowo przekształcić się w urząd, w którym starosta wykonywał swoje obowiązki w zamian za ustalone pobory, natomiast cała reszta trafiała do skarbu państwa ${ }^{39}$. W efekcie dochody Korony wzrosły: w latach 1559-1602 wpływy ze starostw uległy podwojeniu ${ }^{40}$. Arystokracja godziła się (nie od razu) na te zmiany dlatego, że równolegle dokonywano innych: likwidowane były małe lenna, zarządzane przez niższą szlachtę, a ich ziemia wchodziła w skład większych jednostek. Był to jeden z elementów procesu koncentracji dóbr, który wywoływał protesty niższej szlachty. Dodatkowym aspektem reformy było przekształcanie się starosty z niezależnego pana lennego w urzędnika królewskiego - co też wzmacniało pozycję monarchy.

Można również zaobserwować starania monarchów o wyraźniejsze ukazanie ich przewagi nad najbogatszymi magnatami w państwie. Na przykład Fryderyk II wydał w 1562 r. reskrypt zakazujący wznoszenia zbyt wystawnych grobowców, bowiem, jak pisał zirytowany, „przewyższają one królewskie i książęce pochówki, które miały w państwie miejsce" ${ }^{41}$. Dodajmy, że reskrypt został przez szlachtę zlekceważony i dwory, a raczej pałace szlacheckie, nagrobki i kaplice, wystawiane w tym czasie, do dziś imponują swoim bogactwem i rozmachem architektonicznym. Chrystianowi IV doskwierał fakt, że gdy obejmował swoje rządy, żaden z pałaców królewskich nie górował w sposób wyraźny nad siedzibami wielkich magnatów - stąd rozbudowa renesansowego zamku Fredriksborg na północy Zelandii, ale też ideologiczna wymowa wielu zastosowanych w nim plastycznych rozwiązań, wskazujących na imperialne ambicje króla - włącznie z marzeniami o koronie cesarskiej.

Reformacja znacząco zwiększyła zasobność Korony. O ile ok. 1500 r. posiadała ona na własność 15-10 proc. ziemi, to reformacja dodała do tego 30 proc. i w sumie domena królewska obejmowała połowę ziemi w państwie (własność szlachecka - 44 proc.) ${ }^{42}$.

39 Dokładniej zobacz A. Mączak, Dania i Rzeczpospolita, s. 169-170.

40 O. Feldbæk, op. cit., s. 50.

${ }^{41}$ „fast overgik alle kongelige og fyrstelige begravelser, som tilforn er sket her i riget", S. Heiberg, Christian IV, s. 68.

${ }^{42}$ O. Feldbæk, op. cit., s. 8; E. Ladewig Petersen, Kryzys szlachty, s. 156. 
Wyjątkowo zamożny był - i to na tle wielkiego skądinąd bogactwa wielu magnatów - Chrystian IV, choć był on też nieprzeciętnie rozrzutny, co skutkowało nie tylko rosnącym obciążeniem podatkowym, o którym była już mowa, ale też wielkim zadłużeniem państwa - u schyłku swego życia król musiał zastawić swoje insygnia koronne... Faktem jest, że do tej fatalnej sytuacji skarbu państwa przyczynił się nie tylko król, ale też korupcja jego najbliższych współpracowników, a ściśle mówiąc zięciów, przede wszystkim Corfitza Ulfeldta. O skali majątku Chrystiana IV może świadczyć lista jego inicjatyw budowlanych: Fredriksborg, a w Kopenhadze: gmach giełdy, Okrągła Wieża mieszcząca bibliotekę uniwersytecką, dzielnica marynarzy Nyboder, budynki Uniwersytetu, rozbudowa fortyfikacji i portu wojennego. Do tego wielkie uroczystości, od koronacji zaczynając, a kończąc na spektakularnych „Wielkich pokładzinach” (det store bilager), czyli weselu następcy tronu, księcia Chrystiana (1634), które pochłonęło setki tysięcy talarów i wymagało nadzwyczajnego podatku. Do tego trzeba dodać różne merkantylistyczne przedsięwzięcia ekonomiczne, w tym ekspansję kolonialną, zakładanie i rozbudowę miast oraz twierdz czy ekspedycje geograficzne (wyprawa Jensa Munka w poszukiwaniu Przejścia Północno-Zachodniego do Indii). Czapliński przytaczał szacunki duńskich historyków, wedle których w ciągu dwudziestu kilku lat Chrystian IV wydał na swoje inwestycje budowlane około 660 tys. talarów, czyli ponad 1300 tys. ówczesnych złotych polskich!43

Drugą podstawą stosunkowo znaczącej pozycji króla była wspomniana już zdolność związania z Koroną szlacheckich urzędników, którzy nie tylko swoje kariery wiązali z królem (a nie np. z samorządem), dzięki czemu poczuwali się do lojalności względem niego. Uregulowana ścieżka kariery, nacisk na wykształcenie i kwalifikacje dawały stanowi szlacheckiemu w Danii inne cechy (na początku XVII w. około 62 proc. starostów miało wyższe wykształcenie, w połowie stulecia -74 proc. ${ }^{44}$ ). Generalnie spora swoboda króla w nominowaniu na stanowiska wraz z prawem do nobilitacji oznaczały, że z władcą należało się liczyć. Tym bardziej że dzięki temu Oldenburgowie byli w stanie ściągać na dwór królewski w Kopenhadze szlachtę ze swoich rodowych władztw: Szlezwiku i Holsztyna. Choć byli to Niemcy, nie można było ich traktować jak cudzoziemców, bowiem byli „tu urodzeni” i obejmowało ich prawo indygenatu. Szlachta sarkała na szlachtę lub nobilitowanych „chamów” z innych państw niemieckich. Motywy były tu głównie narodowe, a tymczasem dzięki tym ruchom kadrowym król miał do dyspozycji swoje własne,

${ }^{43}$ W. Czapliński, op. cit., s. 64-65.

${ }^{44}$ E. Ladewig Petersen, Fra standssamfund, s. 273. 
dworskie stronnictwo regalistyczne. W chwilach przesileń - jak właśnie w 1660 r. - mogło to mieć znaczenie. Jednakowoż, nie można - mimo takiej samej nazwy - kojarzyć tych grup ze stronnictwami regalistycznymi w sejmach Rzeczypospolitej. Nie składały się one bowiem z „polityków" (czyli posłów lub senatorów), ale głównie z dworzan i urzędników (wojskowych i cywilnych).

Wydaje mi się, że to właśnie w silnej pozycji króla widzieć należy główną przyczynę tego, że po katastrofie wojen Karola X Gustawa Fryderyk III był w stanie zrealizować plan wzmocnienia władzy. Przypomnijmy jednak: pod koniec XV w. monarchowie w obu krajach znajdowali się w bardzo podobnym położeniu - obie godności królewskie były słabe, ich kompetencje bardzo ograniczone. Co konkretnie spowodowało, że w Danii proces szedł w kierunku wzmacniania króla, z tąpnięciem w roku 1648 i kapitulacją Fryderyka III, a w Rzeczpospolitej dokładnie odwrotnie? Tym bardziej że za Kazimierza Jagiellończyka uprawnienia polskiego i litewskiego monarchy były jednak większe niż duńskiego.

Sądzę, że odpowiedź tkwi w reformacji i przyjęciu przez Danię wyznania ewangelicko-augsburskiego, czyli, potocznie mówiąc, luteranizmu, a w wyniku tego także w nowej organizacji Kościoła.

$\mathrm{Na}$ pierwszy rzut oka wydaje się, że to banał. Wiadomo, że wskutek konfiskaty dóbr kościelnych ${ }^{45}$ król w takim kraju stawał się najpotężniejszym właścicielem ziemi, co dawało mu ogromne możliwości polityczne. Drugim źródłem dochodów była dziesięcina, która w większości wpływała teraz do kasy królewskiej. Ale jednocześnie należy zwrócić uwagę, że to bogactwo i możliwości mogły być różnie wykorzystane przykładem choćby Chrystian IV, który mimo zamożności i realnej siły politycznej zostawił kraj w opłakanym stanie, pogrążony w kryzysie, a jego syn, jak to zostało już opisane, został niemal pozbawiony realnych uprawnień do rządzenia. A więc konfiskata ziemi kościelnej nie może być traktowana jako podstawa silnej pozycji monarchy, wynikająca z przyjęcia luteranizmu.

Drugi skutek zmiany wyznaniowej to niemal szkolna formuła: król staje się głową Kościoła. I to jest rzecz niezmiernie kluczowa, należy więc przyjrzeć się jej nieco bliżej. Z jednej strony mamy sytuację administracyjnej amalgamacji instytucji kościelnej (struktury, kompetencji, kadr) z państwem. Monarcha otrzymuje fenomenalne narzędzie sprawnego

${ }^{45}$ Konfiskata miała w pewnym sensie charakter ewolucyjny: początkowo zajęto dobra biskupie, konfiskata posiadłości klasztornych rozłożyła się w czasie (pozwolono bowiem na „naturalne” wygaszanie wspólnot zakonnych), zaś gospodarstwa proboszczów parafialnych w ogóle nie zostały im odebrane, stając się podstawą utrzymania pastorów. 
zarządzania. Jednocześnie jednym ruchem ulega likwidacji Kościół jako struktura konkurencyjna, czyli wykluczająca monopol świeckiego państwa i osłabiająca władzę monarszą. Kościół luterański jest ze względów doktrynalnych podporządkowany państwu - wszelka opozycja wobec tego stanu rzeczy jest nie tylko przestępstwem, ale wręcz grzechem. Wprawdzie podobnie do tej pory postrzegane było każde nieposłuszeństwo wobec pomazańca Bożego, jakim był król, ale co z tego, skoro niezależna od jego władzy struktura kościelna mogła, w razie potrzeby, ogłosić go niegodnym urzędu? I uwolnić poddanych od posłuszeństwa? Nawet jeśli do takich skrajnych sytuacji w epoce wczesnonowożytnej nie dochodziło zbyt często, to sama świadomość tego wystarczała. Katolicki Kościół przedreformacyjny był strukturą alternatywną, podporządkowaną zewnętrznej instancji, której narodowy monarcha nie mógł w pełni kontrolować. Reformacja zniosła ten stan rzeczy. Łącząc obie struktury w jedną, nadając państwu religijny, wręcz teokratyczny charakter (o tym za chwilę), jednocześnie wyraźnie wytyczyła sfery działania: rolą Kościoła i duchowieństwa było wyłącznie czuwanie nad (szeroko pojętym) życiem religijnym ludności. Nie było dla niego miejsca w sferze świeckiego życia: polityce czy własnej aktywności gospodarczej. Symbolem tego było wykluczenie biskupów luterańskich czy, jak ich początkowo nazywano, superintendentów, z Rady Królestwa. Od reformacji instytucja ta stała się całkowicie świecka. Powierzenie Kościołowi zadań stricte ewangelizacyjnych oznaczało także - i działało, acz bardziej długofalowo, na rzecz wzmacniania władzy królewskiej - przekazanie w zarząd państwu szkolnictwa (również uniwersytetu) oraz działalności socjalno-opiekuńczej. Podobnie zresztą jak wycofywanie prawa kanonicznego jako głównego źródła praw i obowiązków Kościoła na rzecz niemiecko-rzymskiego prawa cesarskiego.

Faktem jest, iż w krajach katolickich ówczesnej Europy monarchowie dysponowali często znacznymi kompetencjami wobec kleru i instytucji kościelnej (np. mieli prawo nominacji biskupów lub niższych rangą duchownych), a hierarchowie kościelni należeli często do bliskich współpracowników i sojuszników króla (np. w Rzeczypospolitej senatorowie duchowni stanowili najbardziej regalistyczną część elit władzy). Kościół katolicki pozostał jednak odrębną instytucją w systemie państwa, niezależną i silnie związaną z ośrodkiem ulokowanym poza krajem.

W miarę upływu czasu rozdzielenie funkcji państwa i Kościoła zacierało się, nastąpiło odejście od wyraźnie postulowanego przez Marcina Lutra odseparowania obu struktur i w czasach tzw. ortodoksji luterańskiej państwo uznało się za uprawnione do wtrącania się w sprawy Kościoła, także te ściśle religijne. Jednocześnie rósł wpływ biskupów 
(często profesorów Uniwersytetu Kopenhaskiego) na władzę, ta zaś coraz chętniej obarczała duchownych świeckimi obowiązkami: rodził się Kościół państwowy. Duchowieństwo było nie tylko rojalistyczne, ale też bardzo krytyczne wobec szlachty. Przytoczmy taką znamienną wypowiedź biskupa dotyczącą tego stanu: „uważają, że wszystko zawdzięczają samym sobie, że urodzili się po to, by pogardzać, uciskać i niszczyć biedny lud" ${ }^{46}$. Kiedy indziej znowuż szlachcie grożono gniewem boskim za pazerność w gromadzeniu ziemi kosztem chłopów ${ }^{47}$. Wszystkie dokonane po reformacji przeobrażenia znalazły swą kontynuację i dopełnienie po wprowadzeniu absolutyzmu: przyjęte wówczas zmiany ostatecznie uczyniły z Kościoła ewangelicko-augsburskiego i jego kadr prawdziwy filar państwa duńsko-norweskiego.

Podporządkowanie Kościoła państwu w pierwszym rzędzie oznaczało zmianę w funkcjonowaniu kleru. Zgodnie z przyjętą w 1537 r. ordynacją kościelną ${ }^{48}$, która stała się na niemal dwa stulecia podstawą funkcjonowania Kościoła ewangelicko-augsburskiego w Danii i Norwegii, pastor oraz superintendent w chwili objęcia urzędu składali przysięgę na wierność królowi i zobowiązywali się do czynienia wszystkiego, co przysporzy majestatowi chwały, co pogłębi posłuszeństwo poddanych i przyczyni się do zachowania spokoju w kraju. Takie sformułowania oznaczały, że duchowny przede wszystkim stawał się „człowiekiem króla”, a wśród jego obowiązków, obok ściśle religijnych, znalazło się zadanie oddziaływania na wiernych w duchu „propaństwowym”, czyli wpajanie im posłuszeństwa władzy i lojalności wobec monarchy, a nawet tropienie, czy gdzieś nie kiełkuje nieprawomyślna idea ${ }^{49}$.

${ }^{46}$ Cyt. za: W. Czapliński, op. cit., s. 57.

${ }^{47}$ E. Ladewig Petersen, Fra standssamfund, s. 264-165.

48 Ordynacja kościelna Chrystiana III została opracowana przy współudziale Johanna Bugenhagena, współpracownika Marcina Lutra, i ogłoszona w łacińskiej wersji w 1537 r. W 1539 r. ukazał się oficjalny przekład na język duński. Formalnie ordynacja została zaakceptowana na zjeździe szlachty w Odense w 1539 r. Norweska wersja, czyli nieco zmieniony i dostosowany (w niewielkim stopniu) do norweskich warunków tekst został przyjęty w roku 1607.

49 Pastor: „Jeg NN, der er valgt til sognepræst for menigheden i NN, lover min nådigste herre, kongen, troskab. Jeg vil fremme det, der kan være hans kongelige majestæt til ære, lydighed og fred.”; Superintendent: „Jeg NN, der er valgt til superintendent over NN stift, lover Deres kongelige Majestæt sand troskab, at jeg så meget det er mig muligt vil fremme det, som kan være Deres kongelige Majestæt og riget til ære, gavn, fred, rolighed og lejlighed, samt andet, som jeg over for Gud er Deres kongelige Majestæt pligtig, og at jeg vil bekæmpe alt, hvad der kan hindre dette", http://www. lutherdansk.dk/Trellix/id134.htm (dostęp: 17 VII 2017); E. Ladewig Petersen, Fra standssamfund, s. 228. 
Na tym gruncie można rozpatrywać różne formy relacji między klerem a monarchą. $\mathrm{Z}$ jednej strony było to narzucanie przez niego duchowieństwu określonych standardów funkcjonowania, także co do kwalifikacji. Ordynacja z 1537 r. nie tylko opisywała wymagania wobec pastora, ale też wymieniała, jakie książki winny znajdować się w jego podręcznej bibliotece. W 1569 r. reskrypt królewski zalecał, by kandydat na pastora miał za sobą „pobyt na uniwersytecie” - zwyczajowo przyjmowano, że wystarczy jeden rok studiowania. W 1629 r. wprowadzono zasadę, że tylko pomyślne zdanie egzaminu teologicznego daje możliwość objęcia stanowiska księdza. Praktycznie spełnienie tego wymogu wiązało się z koniecznością ukończenia studiów wyższych, przede wszystkim na Uniwersytecie w Kopenhadze.

Charakterystyczne jest, jak dalece monarchowie postrzegali duchownych jako swoich urzędników, oczekując od nich wypełniania różnych funkcji, często dalekich od ewangelizacji. Pastor był głównym dostarczycielem informacji dla państwa. Nie tylko tych związanych z prowadzeniem ksiąg parafialnych, jak zresztą w całej Europie. Pastorowie mieli także wspierać inne inicjatywy. Na przykład, kiedy wybitny uczony, z zawodu lekarz, z zamiłowania historyk, Ole Worm postanowił zebrać wszystkie inskrypcje runiczne w monarchii w celu ich publikacji, zadaniem ich odnalezienia, odczytania, przepisania i dostarczenia do Kopenhagi król Chrystian IV obarczył lokalnych księży.

Duchowny zarazem uzyskał różne uprawnienia, które wzmacniały jego władzę nad wiernymi. Najważniejszy był reskrypt z 1629 r., w którym pastor, wraz z radą parafialną, otrzymywał prawo kontrolowania zachowania parafian i karania ich nie tylko za występki przeciw obyczajności, ale też za niedostateczną wiedzę na temat prawd wiary - w praktyce chodziło o dobrą znajomość Małego katechizmu Lutra. Kary, które Kościół mógł nakładać na wiernych, były liczne: poczynając od grzywny i pręgierza, a kończąc na wykluczeniu ze wspólnoty oraz banicji (kara bardzo rzadko stosowana). Okólnik królewski z 1630 r. opisywał obrządek domowy, do którego każdy wierny był zobowiązany, czyli codzienną lekturę (na głos) katechizmu Lutra przez ojca rodziny. Gospodarz był także zobowiązany do uczenia członków rodziny, w tym służby, czytania. Pastor miał sprawdzać, czy obowiązki te były rzeczywiście wypełniane.

Ambona służyła nie tylko do ewangelizacji, ale też do ogłaszania królewskich decyzji. Służyła także do nieustannego przypominania słuchaczom - a pamiętajmy, że główną częścią luterańskiego obrządku było trwające wówczas około godziny kazanie - że wierność, posłuszeństwo władzy, lojalność wobec monarchy to podstawowe obowiązki chrześcijanina. Wedle duńskiego historyka Benito Scocozzy „dokonało się stopienie 
duchownej i świeckiej władzy w osobie króla, co nie dawało możliwości schronienia się w cieniu autorytetu niezależnego Kościoła wówczas, gdy władza świecka wyciągała swe ramię po prostego człowieka"50.

Osobną sferą była działalność edukacyjna - szkoła mogła być, obok kościoła parafialnego, kolejnym miejscem, w którym wdrażano wiernych nie tylko do chrześcijańskiej postawy i wiary, ale też do sumiennego wypełniania obowiązków poddanego Jego Królewskiej Mości. Ordynacja kościelna poświęcała szkołom osobny rozdział. Na wstępie znalazł się taki passus:

W szkole dzieci należy nauczać i przygotowywać ich umysł do Ewangelii. Dzięki temu przygotowaniu w dzieciństwie wdraża się do prawdziwej chrześcijańskiej pobożności [dosł. bojaźni bożej - K.S.] i innych cnót. Dzieci przyswajają sobie umiejętności, które mają duże znaczenie, jeśli chodzi o wiedzę na temat Bożej chwały w chrześcijaństwie, ale też wszystko to, co przyczynia się do prowadzenia dobrego życia w społeczeństwie i utrzymania świeckiej władzy ${ }^{51}$.

Szkoły miały być zakładane w miastach, choć zaznaczano, że mają z nich korzystać dzieci mieszkające w okolicznych wioskach oraz mniejszych miasteczkach, nauczanie zaś zaczynało się od zdobycia umiejętności pisania. Wyższe klasy miały już rozbudowany program edukacji teologicznej, ale też klasycznej - naukę łaciny, greki i hebrajskiego, i ordynacja wskazuje, że jednym z celów tych szkół miało być przygotowanie do studiów teologicznych kandydatów na duchownych. Ordynacja wspomina też o „szkołach [uczących] pisania” dla dziewcząt i chłopców, które miały być prowadzone na wsi, na koszt państwa ${ }^{52}$. Tym nauczaniem miał się zajmować raz w tygodniu kościelny (degn). W jakimś stopniu mógł ten zapis być nawiązaniem do ambitnego planu Chrystiana II, który w 1521 r. (czyli jeszcze przed oficjalnym wprowadzeniem luteranizmu) wydał reskrypt nakazujący proboszczom (w razie zgłoszenia się

${ }^{50}$ Cyt. za: W. Czapliński, op. cit., s. 58.

51 „I skolen kan børn opdrages og få sindet beredt til evangeliet. Ved denne forberedelse gør man den første barndom egnet til sand kristen gudsfrygt og andre dyder. Børnene tilegner sig de kundskaber, som har stor betydning, når det drejer sig om enten at lære det, der hører til Guds ære i kristendommen, eller at lære det, der hører til at opholde og bevare et godt civilt liv og det verdslige styre", http://www.lutherdansk. dk/Trellix/id134.htm (dostęp: 14 VII 2017).

52 „De såkaldte «skrive-skoler» for drenge og piger og andre, der ikke dur til at lære latin, må øvrigheden betale. Dog skal forstanderne for disse skoler holde øje med, at sand gudsfrygt indpodes disse børn med børnelærdommen", http://www.lutherdansk.dk/Trellix/id134.htm (dostęp: 14 VII 2017). 
chętnych) nauczanie wiejskich dzieci czytania, pisania i podstaw religii. Prawo to, podobnie jak wiele innych decyzji tego króla, zostało po jego obaleniu odwołane.

Szkolnictwo, podobnie jak system opieki społecznej, który zgodnie z zasadami luteranizmu także miało przejąć państwo, działało bardzo słabo ${ }^{53}$, prawdziwy postęp zaczął się dokonywać po wprowadzeniu absolutyzmu ${ }^{54}$. Nie można jednak zapominać, że nawet tak niedoskonały system wpływał na stosunek ludzi do państwa i Korony i był ważnym elementem wypełniania przez Kościół luterański zadania dyscyplinowania ludności. Jak pisze Steffen Heiberg: „Podwójna rola księdza, jako duchowego autorytetu oraz reprezentanta władzy państwowej miała duże znaczenie dla politycznej i społecznej stabilności, która cechowała Danię od XVII do XX w."55.

Swoje znaczenie miał też przekaz ideologiczny, płynący z góry, choć siłą rzeczy docierał on raczej do elit. Jego głównym elementem było ukazanie króla jako najważniejszego gwaranta utrzymania prawdziwej wiary, pomazańca Bożego wskazanego bezpośrednio przez Opatrzność do realizacji jej celów w doczesnej rzeczywistości. Dobitnie mówiono o tym w chwili koronacji - pewien model przedstawiony w 1537 r. przez Johanna Bugenhagena w trakcie ceremonii koronacyjnej króla Chrystiana III i jego żony Doroty był potem powtarzany w trakcie kolejnych ${ }^{56}$. W symbiozie z tymi koncepcjami pozostawała osobista pobożność kolejnych władców, zwłaszcza Chrystiana III i jego wnuka, Chrystiana IV. Zwraca uwagę np. sarkofag Chrystiana III, przedstawiający króla w pozycji klęczącej, w trakcie modlitwy, albo obraz, na którym Chrystian IV, w szacie pokutnej, bez jakichkolwiek oznak władzy, klęczy przed Chrystusem (wiszący w prywatnej kaplicy tego władcy w zamku Fredriksborg). Charakterystyczne jest, jak zmieniły się po reformacji dewizy monarsze - zwyczaj dobierania jakiejś sentencji, która byłaby mottem dla władcy zapoczątkował Chrystian I. Trzej pierwsi Oldenburgowie przyjmowali sentencje, by tak rzec, o filozoficznym charakterze: w kolejności chronologicznej: „Virtuti monstrante viam”, „Pro lege et grege”, „Sic errat in fatis”. Od Chrystiana III

${ }^{53}$ E. Ladewig Petersen, Fra standssamfund, s. 218.

${ }^{54}$ W 1708 r. wydano prawo zwalniające z opłat za szkołę dzieci z ubogich rodzin, w 1721 r. król Fryderyk IV zaczął zakładać w swoich dobrach szkoły dla wiejskich dzieci; po wprowadzeniu obowiązkowej konfirmacji w 1736 r. Chrystian VI wydał w 1739 prawo o obowiązku szkolnym dla wszystkich dzieci.

55 „Præstens dobbeltrolle som åndelig autoritet og repræsentant for statsmagten har haft stor betydning for den politiske og sociale stabilitet, der har kendetegnet Danmark fra 1600- til 1900-tallet", S. Heiberg, Christian IV, s. 131.

${ }^{56}$ E. Ladewig Petersen, Fra standssamfund, s. 227. 
nabrały one wybitnie religijnego, by nie powiedzieć dewocyjnego charakteru: „Spes mea solus Deus” (w niemieckiej wersji: „Zu Gott mein Trost allein”), „Deus refugiu et fidusia mea” („Mein' Hoffnung zu Gott allein”), „Regna firmat pietas”, „Dominis providebit”. Ani Chrystian IV, ani Fryderyk III nie przyjęli sentencji w niemieckiej wersji. Pierwsza, w pełni „świecka” dewiza pojawiła się, nawiasem mówiąc, w chwili objęcia tronu przez Fryderyka V (1746, „Prudentia et constantia”).

Oddziaływanie propagandy królewskiej oraz Kościoła dotyczyło też szlacheckich elit. One również miały funkcjonować w ramach jednolitego wyznaniowo państwa, musiały także uznać religijny wymiar władzy królewskiej i zgodzić się na podporządkowanie Kościołowi jako części struktury państwa. Może to właśnie tłumaczy, dlaczego szlachta w krytycznych chwilach potopu szwedzkiego nie zareagowała na apele Ulfeldta. Nie dając wiary jego argumentom, że Fryderyk III to tyran, który pragnie ograbić szlachtę z jej wolności. Może to też tłumaczy, dlaczego dla szlachty naturalne było postrzeganie urzędu jako służby i podporządkowanie się królowi, a nie szukanie pozycji klienta u możnego magnata. Wiara i głęboka religijność, typowa dla XVII w., w takim samym stopniu co rewolucja naukowa, w doktrynie luterańskiej miała rojalistyczny (a zarazem wybitnie konserwatywny w kwestiach społecznych) charakter: władzę króla można było ograniczyć w kapitulacjach, ale przeciw królowi buntować się nie było można (nawet jeśli taki zapis tam się znalazł). Nie pozwalała na to ani religia, ani pastor, nie mówiąc o biskupie.

Antoni Mączak podkreślał fakt, że „tak znaczny odsetek zdolnej młodzieży szlacheckiej przeszedł w półwieczu przed absolutystycznym zamachem stanu Fryderyka III przez gruntowne wychowanie w służbie króla"57. Można by odnieść wrażenie, że jakaś grupa szlachty poparła zamach stanu króla. Nic takiego nie miało miejsca, większość szlachty i arystokracji była przeciw, natomiast okazała się niezdolna do działania. Skąd ten paraliż? Czy ze świadomości, że po stronie władcy stoi mieszczaństwo Kopenhagi i kler luterański? Czy wskutek umiejętnych manewrów oraz manipulacji najbliższych współpracowników króla? Czy też może dlatego, że szlachta czuła ciężar zarzutów: krytykę, że nie sprostała swoim obowiązkom, że nie broniła ojczyzny $z$ takim poświęceniem jak powinna i że w związku z tym nie należą jej się żadne przywileje? Każdy z tych czynników odegrał jakąś rolę, ale to, co przede wszystkim skrępowało szlachcie ręce, było wpojone przez Kościół przekonanie, że z pomazańcem Bożym i głową Kościoła nie można walczyć jak ze zwykłym

\footnotetext{
57 A. Mączak, Dania i Rzeczpospolita, s. 175.
} 
przeciwnikiem politycznym. Mówiąc krótko: zasada, że król jest primus inter pares była w Danii rządzonej przez szlachtę nie do pomyślenia.

Nie będziemy tu oczywiście proponować monokauzalnej wykładni genezy absolutyzmu, a zatem i wyjaśnienia, jak monarchia Oldenburgów zdołała wyjść z kryzysu państwa w latach pięćdziesiątych XVII w. Wiadomo, że istotne znaczenie miał fakt, iż król zdołał oprzeć się na alternatywnej bazie politycznej: duchowieństwie i mieszczaństwie Kopenhagi (do czego na przykład jego ojciec nie był zdolny, z pogardą wypowiadając się o „kramarzach” ). Wiadomo, jaką rolę odegrała grupa jego współpracowników (w tym szwagier Hannibal Sehested). Wiadomo też, jak ważna była popularność króla, jego wielki autorytet (inaczej niż Jan Kazimierz, Fryderyk stał się symbolem walki o wolność ojczyzny), a zarazem jak powszechna była świadomość kryzysu państwa, poczucie, że zmiany są konieczne. Swoją rolę odegrało też pewne pęknięcie w stanie szlacheckim: rosnąca niechęć niższej szlachty do arystokracji i Rady Królestwa. Wszystkie te elementy układanki nie będą jednak stanowić całości, nie „ożyją", jeśli nie dodamy do nich spoiwa: propaństwowej, rojalistycznej i wzmacniającej legalizm doktryny ewangelicko-augsburskiej.

Przyjęcie przez Danię wyznania ewangelicko-augsburskiego oraz Grevens fejde z lat trzydziestych XVI w. mogą potwierdzać tezę o tym, że dla dziejów nowożytnych państw europejskich ogromne, być może rozstrzygające znaczenie miały wypadki na początku XVI w. Mam tu na myśli zaburzenie społeczne, często o ogromnej skali (Grevens fejde jest przecież częściowo duńskim odpowiednikiem wojny chłopskiej w krajach niemieckich), rewolucje gospodarcze, rozłam zachodniego chrześcijaństwa. Nie mniej ważne były zachodzące w tym czasie, związane z formowaniem się narodowych państw dynastycznych przetasowania polityczne (w ramach tego procesu dokonało się w Skandynawii wchłonięcie Norwegii przez Danię w 1536 r. oraz utworzenie suwerennej Szwecji pod rządami Gustawa Erikssona w 1523 r. $)^{58}$. O tym, jaki wpływ na dzieje Polski miał fakt, że wielkie te zawirowania w dużym stopniu ominęły ziemie polskie, pisał Janusz Tazbir: szlachta uwierzyła, że żyje w porządku doskonałym.... ${ }^{59}$ Ominął ją zimny prysznic, dzięki któremu można było uniknąć wielu błędów.

Może kusić sformułowanie na gruncie przedstawionych tez poglądu, że gdyby w XVI w. w Koronie i na Litwie bezapelacyjnie zwyciężył luteranizm, to państwo by ocalało i do jego upadku by nie doszło. Takie

586 czerwca 1523 r. Gustaw został obwołany królem przez szwedzki Riksdag, koronował się w styczniu $1528 \mathrm{r}$.

59 Polska na przestrzeni wieków, red. J. Tazbir, Warszawa 1995, s. 227. 
tezy zresztą w historiografii polskiej się pojawiały. Nie mają one jednak większego sensu. I nie chodzi o to, że gdybanie w historii jest czynnością jałową, bo pisanie alternatywnych dziejów może być pouczającą rozrywką intelektualną. Przede wszystkim dlatego, że ten sam czynnik w innym miejscu, w innym środowisku dziejowym, mógł odegrać inną rolę.

\section{Streszczenie}

W epoce wczesnonowożytnej monarchia duńska oraz Rzeczpospolita wykazywały wiele podobieństw. Gospodarka była zdominowana przez rolnictwo i przez długi czas dość monokulturowa, czego efektem była koniunktura i pomyślny rozwój w wieku XVI oraz powolny regres w XVII. W społeczeństwie hegemonem była szlachta, która zdołała podporządkować sobie chłopstwo oraz mieszczaństwo oraz zdobyć faktyczną władzę w państwie. Choć nie powstała w Danii instytucja stałej reprezentacji stanowej, jak polski sejm, to władzę w imieniu stanu szlacheckiego sprawowała Rada Królestwa. Był to specyficzny system oligarchiczny, zbliżony do rządów magnaterii w Rzeczypospolitej. Prerogatywy monarsze były ograniczone, w niektórych okresach dość mocno. Jednak, odmiennie niż w Rzeczypospolitej, w dłuższym okresie obserwuje się raczej wzmacnianie władzy królewskiej, co wynikało nie tylko z relatywnie większej zamożności Korony czy większej roli mieszczaństwa, ale przede wszystkim ze statusu i pozycji monarchy, co było skutkiem przyjęcia luteranizmu. Dosłowne traktowanie zasady pochodzenia władzy królewskiej od Boga, podporządkowanie Kościoła królowi, głębokie utożsamianie się duchowieństwa z interesem Korony oraz jego wprzęgnięcie do pracy nad dyscyplinowaniem i wychowywaniem społeczeństwa w duchu rojalizmu, posłuszeństwa władzy i przestrzegania prawa, to główne elementy sytuacji, w której monarcha nie mógł być postrzegany tylko jako polityczna siła, przeciw której można było się bezkarnie buntować. Wszystkie te czynniki pomogły Fryderykowi III przeprowadzić w 1660 r., w momencie głębokiego kryzysu po dramatycznych wojnach ze Szwecją, absolutystyczny zamach stanu, dzięki któremu Dania zdołała - w przeciwieństwie do Rzeczypospolitej - zreformować państwo i uzyskać wewnętrzną stabilizację.

\section{A Crisis of Statehood in the Mid-Seventeenth Century: A Parallel between Denmark and the Polish-Lithuanian Commonwealth}

There were many similarities between the Danish Kingdom and the Polish-Lithuanian Commonwealth in the early modern period. Their economy was dominated by agriculture, quite monocultural for a long time, which resulted in an economic boom in the sixteenth century and a gradual regress in the next century. The nobility held the hegemonic position in the country, and managed to subject peasants and burghers to their authority, after taking actual power in the state. Despite the 
fact that there was no permanent representative institution of the estates, such as the Polish Sejm, power in Denmark was wielded on behalf of the noble estate by the Council of the Realm. It was a specific oligarchic system, similar to the rule of magnates in the Commonwealth. The king's prerogatives were reduced, in some periods quite significantly. But, unlike in Poland, in a longer time horizon, royal power was strengthened rather than weakened, not only because of the relatively greater wealth of the Crown or role of burghers, but mainly because of the status and position of the king resulting from the country's conversion to Lutheranism. This brought about a literal interpretation of the principle that the royal power was given by God, the subjection of the Church to the king, a deep identification of the clergy with the Crown's interests and their work on disciplining and educating the people in the spirit of royalism, obedience to power and laws. All this created the situation in which it was impossible to regard the king merely as a political force, and rebel against him with impunity. This helped King Frederick III convert the elective monarchy into an absolute monarchy in 1660, when the state was hit by a severe crisis after the dramatic wars with Sweden. Thanks to that, Denmark - unlike the Polish-Lithuanian Commonwealth - managed to introduce internal reforms and regain its stability.

Translated by Grażyna Waluga

\section{Bibliografia}

Czapliński Władysław, Dzieje Danii nowożytnej 1500-1975, PWN, Warszawa 1982.

Feldbæk Ole, Danmarks økonomiske historie 1500-1840, systime, Herning 1993.

Heiberg Steffen, Christian IV - en europoeisk statsmand, Gyldendal, København 2006. Heiberg Steffen, Enhjørningen. Corfitz Ulfeldt, Gyldendal, København 1993.

Heise Arnold, Frederik I, w: Dansk biografisk Lexikon, t. 5, red. Carl Frederik Bricka, Gyldendalske Boghandels Forlag (F. Hegel \& Søn), Kjøbenhavn 1891.

Historia Polski w liczbach, t. 1: Państwo, społeczeństwo, red. Andrzej Wyczański [et al.], Zakład Wydawnictw Statystycznych, Warszawa 2003.

http://danmarkshistorien.dk/leksikon-og-kilder/vis/materiale/selvejerboender-

-ca-1000-1700/?no_cache=1\&cHash=f1504f1fe8f3c1ddede9e01df2e7300c

http://www.denstoredanske.dk

http://www.lutherdansk.dk/Trellix/id134.htm

Imsen Steinar, Winge Harald, Norsk historisk leksikon. Kultur og samfunn ca. $1500-$ ca. 1800, Cappelen Akademisk Forlag, Oslo 1999.

Johansen Hans Christian, Danish Population History 1600-1939, University Press of Southern Denmark, Odense 2002.

Ladewig Petersen Erling, Fra standssamfund til rangssamfund 1500-1700. Dansk social historie, t. 3, Gyldendal, København 1980.

Ladewig Petersen Erling, Kryzys szlachty duńskiej 1580-1660, w: Europa i świat w początkach epoki nowożytnej, cz. 1: Społeczeństwo, kultura, ekspansja, red. Antoni Mączak, Wiedza Powszechna, Warszawa 1991.

Lausten Martin Schwarz, Danmarks kirkehistorie, Gyldendal, København 1987. 
Mączak Antoni, Dania i Rzeczpospolita w dobie nowożytnej. Problemy i perspektywy badań porównawczych, ZH 47, 1982, 4, s. 167-180.

Mączak Antoni, Rządzacy i rządzeni. Władze i społeczeństwo w Europie wczesnonowożytnej, PIW, Warszawa 1986.

Polska na przestrzeni wieków, red. Janusz Tazbir, PWN, Warszawa 1995.

Scocozza Benito, Jensen Grethe, Politikens etbinds Danmarks historie, Politikens Forlag A/S, [København] 2004.

Schultz Danmarkshistorie. Vort folks historie gennem tiderne skrevet af danske historikere, t. 2, red. Aage Friis, Axel Linvald, M. Mackeprang, J.H. Schultz Forlag, København 1941.

Szelągowska Krystyna, My Norwegowie. Tożsamość narodowa norweskich elit w czasach nowożytnych, Avalon, Kraków 2011.

Szelągowska Krystyna, O tym, jak pani Lykke z chłopami i królem wojowała, czyli o kobiecie interesu w XVI-wiecznej Danii-Norwegii, „Studia Podlaskie” 19, 2011, s. 101-114.

Wolter Hans Christian, Adel og Embede. Embedsfordeling og karrieremobilitet hos den dansk-norske adel 1588-1660, Den danske historiske Forening, København 1982 (Skrifter udgivet af det Historiske Institut ved Københavns Universitet, t. 13).

Biogram: Krystyna Szelągowska, dr hab., profesor Uniwersytetu w Białymstoku, zajmuje się dziejami powszechnymi nowożytnej Skandynawii oraz historią historiografii; kontakt: k.szelagowska@gazeta.pl. 